Article

\title{
Optimization of the QuEChERS-Based Analytical Method for Investigation of 11 Mycotoxin Residues in Feed Ingredients and Compound Feeds
}

\author{
Hyungju Seo ${ }^{1,+}{ }^{\mathbb{D}}$, Sunyeong Jang ${ }^{1,+}$, Hyeongwook Jo ${ }^{2} \mathbb{D}$, Haejin Kim ${ }^{1}$, Seunghwa Lee ${ }^{1}$, Hyejeong Yun ${ }^{1}$, \\ Minhee Jeong ${ }^{1}$, Joonkwan Moon ${ }^{2}$, Taewoong $\mathrm{Na}^{1, *}$ and Hyunjeong Cho ${ }^{1, *}$ \\ 1 Experiment Research Institute, National Agricultural Products Quality Management Service, 141, \\ Yongjeon-ro, Gimcheon-si 39660, Korea; hlhl103@naver.com (H.S.); wts1424@naver.com (S.J.); \\ asarela00@korea.kr (H.K.); shlee96@korea.kr (S.L.); yhj1217@korea.kr (H.Y.); miniya33@korea.kr (M.J.) \\ 2 Hansalim Agro-Food Analysis Center, Hankyong National University Industry Academic Cooperation \\ Foundation, Suwon 16500, Korea; hyeongwook.jo@hknu.ac.kr (H.J.); jkmoon264@gmail.com (J.M.) \\ * Correspondence: naratw@korea.kr (T.N.); hjcho201@korea.kr (H.C.); Tel.: +82-54-429-7813 (T.N.); \\ +82-54-429-7810 (H.C.) \\ + These authors contributed equally to this work.
}

Citation: Seo, H.; Jang, S.; Jo, H.; Kim, H.; Lee, S.; Yun, H.; Jeong, M.; Moon, J.; Na, T.; Cho, H.

Optimization of the

QuEChERS-Based Analytical Method for Investigation of 11 Mycotoxin Residues in Feed Ingredients and Compound Feeds. Toxins 2021, 13, 767. https://doi.org/10.3390/ toxins13110767

Received: 30 September 2021

Accepted: 27 October 2021

Published: 29 October 2021

Publisher's Note: MDPI stays neutral with regard to jurisdictional claims in published maps and institutional affiliations.

Copyright: (C) 2021 by the authors Licensee MDPI, Basel, Switzerland. This article is an open access article distributed under the terms and conditions of the Creative Commons Attribution (CC BY) license (https:// creativecommons.org/licenses/by/ $4.0 /)$.

\begin{abstract}
Mycotoxins are toxic substances naturally produced by various fungi, and these compounds not only inflict economic damage, but also pose risks to human and animal health. The goal of the present study was to optimize the QuEChERS-based extraction and liquid chromatography-tandem mass spectrometry (LC-MS/MS) method for the analysis of 11 mycotoxins, such as aflatoxins (AFs), ochratoxin A (OTA), fumonisins (FBs), T-2 toxin, HT-2 toxin, zearalenone (ZEN), and deoxynivalenol (DON), commonly found in feed. The QuEChERS method, characterized by being "quick, easy, cheap, effective, rugged, and safe", has become one of the most common extractions and cleanup procedures for mycotoxin analyses in food. Therefore, in this experiment, an optimal method for the analysis of 11 mycotoxins in feed was established by modifying the general QuEChERS method. In this process, it was confirmed that even if feed samples of different weights were extracted, the quantitative value of mycotoxins in the feed was not affected. To reduce matrix effects, 13C-labeled compounds and deuterium were used as internal standards. This optimized method was then applied in the determination of 11 mycotoxins in 736 feed ingredients and compound feeds obtained from South Korea. The results showed that the occurrence rates of FBs, ZEN, and DON were $59.4 \%, 38.0 \%$, and 32.1\%, respectively, and OTA, AFs, and T-2 toxin and HT-2 toxin were found in fewer than $1 \%$ of the 736 feeds. The mean concentration ranges of FBs, ZEN, and DON were 757-2387, 44-4552, and 248-9680 $\mu \mathrm{g} / \mathrm{kg}$, respectively. Among the samples in which DON and ZEN were detected, 10 and 12 samples exceeded the management recommendation standards presented by the Ministry of Agriculture, Food and Rural Affairs (MAFRA). However, when the detected concentrations of DON and ZEN were compared with guideline levels in foreign countries, such as the US, Japan, China, and the EU, the number of positive samples changed. In addition, the co-occurrence of mycotoxins in the feed was analyzed, and the results showed that $43.8 \%$ of the samples were contaminated with two or three mycotoxins, among which the co-occurrence rate of FBs, ZEN, and DON was the highest. In conclusion, these results suggest the need for stricter management standards for FBs, DON, and ZEN in South Korea, and emphasize the importance of the continuous monitoring of feeds.
\end{abstract}

Keywords: mycotoxin; feed; investigation; QuEChERS; LC-MS/MS

Key Contribution: We optimized QuEChERS-based extraction and LC-MS/MS method for the analysis of 11 mycotoxins in feed. This optimized method was then applied to the investigation of 11 mycotoxins in 736 feed ingredients and compound feeds. 


\section{Introduction}

Mycotoxins are toxic secondary metabolites formed by fungi in genera such as Alternaria, Aspergillus, Fusarium, and Penicillium [1]. Currently, more than 500 types of mycotoxins have been identified worldwide [2]. Among the various mycotoxins, the major ones are aflatoxins (AFs), formed by A. flavus and A. parasticus; ochratoxins (OTs), produced by $A$. ochraceus, $A$. carbonarius, and $P$. verrucosum; trichothecenes, including type A (T-2 and HT-2 toxins) and type B (fumonisins (FBs), zearalenone (ZEN), and deoxynivalenol (DON)), mainly formed by Fusarium species (Figure 1); and ergot alkaloids, produced by Claviceps [3]. The occurrence of mycotoxins depends on factors such as the species of fungi and the host plant species. It is also influenced by climate conditions, including temperature, moisture, and relative humidity before/after harvest and between distribution and storage $[4,5]$. Humans and animals can be affected by ingesting food and feed contaminated with mycotoxins, or indirect mycotoxin transmission can occur when humans ingest products such as milk, eggs, and meat from livestock that has eaten feed contaminated with mycotoxins [6-11]. These toxic compounds pose health risks such as carcinogenic, teratogenic, mutagenic, nephrotoxic, and hepatotoxic effects in humans and animals, and they also have the potential to cause enormous economic losses in agriculture [12,13]. For example, FBs can induce sphingolipid metabolism disorders and activate ER stress to cause gastrointestinal damage; DON causes acute/temporary nausea, vomiting, diarrhea, abdominal pain, headache, dizziness, and fever in animals and humans; and ZEN causes hormonal imbalances in the body, which can lead to numerous diseases of the reproductive system such as prostate, ovarian, cervical, or breast cancers [14-16]. In particular, the International Agency for Research on Cancer (IARC) has classified DON, T-2 toxin, HT-2 toxin, and ZEN as possible human carcinogens (Group 3); FBs and ochratoxin A (OTA) as human carcinogens (Group 2B); and AF as a human carcinogen (Group 1) [17]. These toxic substances are chemically stable and do not degrade easily at high temperatures, and a single fungal species can produce various types of mycotoxins $[18,19]$. For these reasons, many countries have established and strictly managed maximum residue limits (MRLs) of major mycotoxins in food and feed [20]. In general, there are several important factors to consider when extracting various mycotoxins from feed. First, since each mycotoxin has specific physical and chemical properties, a solvent suitable for each mycotoxin must be selected for its extraction $[18,21]$. For example, FBs are hydrophilic mycotoxins and thus soluble in polar solvents, and AFs, which are hydrophobic mycotoxins, are soluble in non-polar solvents [18]. Second, the sampling and homogenization processes play important roles in determining the identity and amount of mycotoxins. This is because mycotoxin-producing fungi do not grow uniformly on the substrate, and contamination with natural specimens is not homogeneous [22]. Therefore, the sampling procedure and the homogenization process in the preparation stage before sample extraction can significantly affect the measurement of mycotoxins [23]. For this reason, the Ministry of Agriculture, Food and Rural Affairs (MAFRA) recommends passing the pulverized feed through a sieve of 20 mesh $(850 \mu \mathrm{m})$, and the weight of the feed used for pretreatment should be set to $25 \mathrm{~g}$ [24]. The third factor is that feed is a complex matrix because various materials are included, and any interfering substances that remain after extraction can affect instrument analysis; hence, matrix effects must be reduced through a clean-up process [18,22,25].

For accurate qualitative and quantitative analyses that account for these physicochemical properties related to mycotoxins, molecular biology methods, such as enzymelinked immunosorbent assay (ELISA), and instrument methods, including thin-layer chromatography (TLC), gas chromatography (GC), liquid chromatography (LC), and liquid chromatography-tandem mass spectrometry (LC-MS/MS), have been proposed for the analysis of mycotoxins [19]. Among them, LC-MS/MS is used for comprehensive mycotoxin analysis due to its high selectivity, high sensitivity, and ability to analyze many mycotoxins in a short time. However, quantitative analysis with LC-MS/MS can be influenced by matrix effects when an electrospray ionization source (ESI) is used [26]. The matrix effect is a change in the ionization efficiency of a compound due to the pres- 
ence of a substance that elutes with the analyte of interest [27]. The matrix effect can be addressed by using certain calibration approaches, including matrix-matched calibration, the standard addition method, and through the use of internal standards [27]. In particular, internal standards are widely used in mass spectrometry not only to correct for sample preparation variations during extraction and chemical derivatization, but also to compensate for variability in signal intensity due to ion suppression caused by matrix components that may influence the efficiency of ionization [28-30].
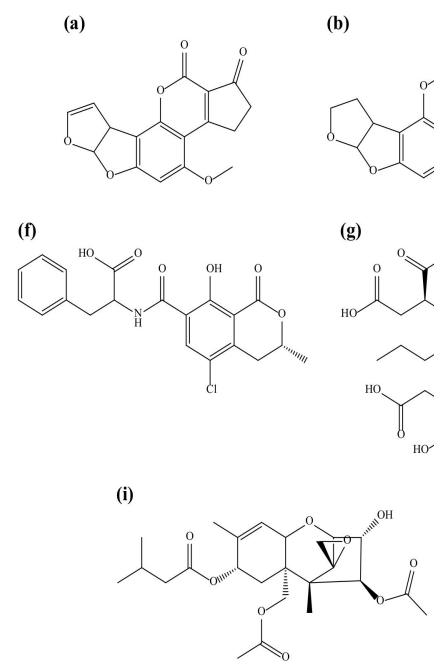

(b)

(g)
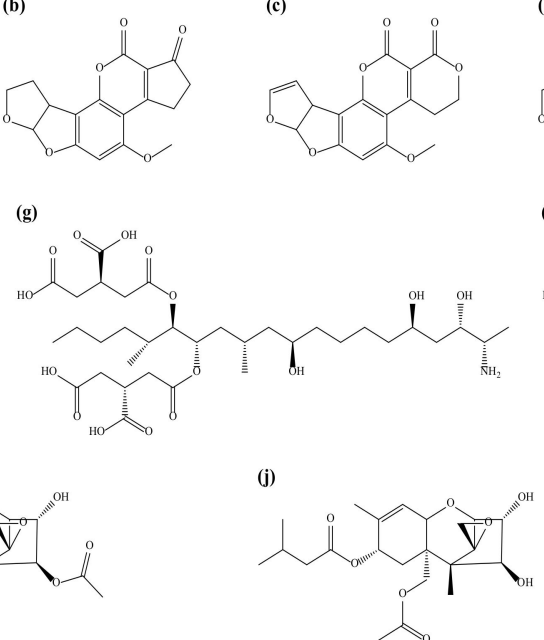

(d)

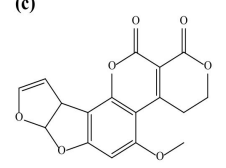

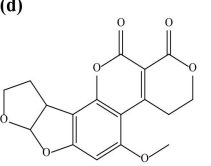
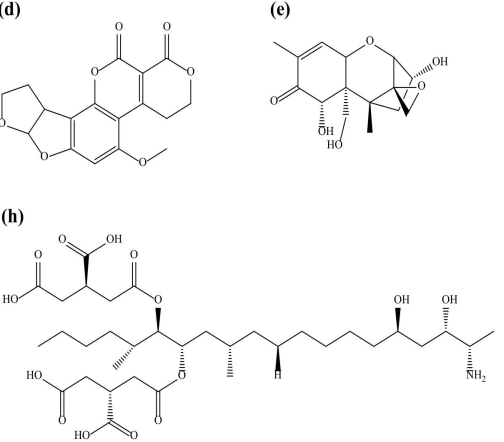

(k)

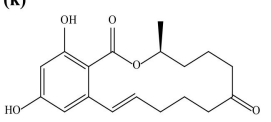

Figure 1. Chemical structures of the 11 mycotoxins: (a) aflatoxin $\mathrm{B}_{1} ;(\mathbf{b})$ aflatoxin $\mathrm{B}_{2} ;(\mathbf{c})$ aflatoxin $\mathrm{G}_{1} ;(\mathbf{d})$ aflatoxin $\mathrm{G}_{2}$; (e) deoxynivalenol; (f) ochratoxin $\mathrm{A}$; (g) fumonisin $\mathrm{B}_{1}$; (h) fumonisin $\mathrm{B}_{2}$; (i) T-2 toxin; (j) HT-2 toxin; (k) zearalenone.

Recently, a method of mycotoxin analysis using "quick, easy, cheap, effective, rugged, and safe" (QuEChERS)-based HPLC-MS/MS on various matrices, including food and feed, was demonstrated [21,31-34]. QuEChERS is mainly used for the analysis of pesticides, and it can be tailored to the chemical properties of various mycotoxins by using acetonitrile and water as extraction solvents [35]. In addition, the matrix effect can be minimized by using a clean-up process with a material such as primary secondary amine (PSA) or octadecyl-modified silica (C18) [36]. In recent years, several methods have been presented for mycotoxin analysis using LC-MS/MS in which quantification was attempted using a matrix-matched calibration curve $[32,37,38]$. This correction also helps to reduce matrix effects but the required preparation can be time- and labor-intensive, as each matrix requires a matrix-matched calibration curve, which is cumbersome when studying multiple matrices. It is also difficult to find a feed that does not contain mycotoxins to use as a matrix [39]. In addition, in previous studies in which mycotoxin analysis was performed using QuEChERS-based LC-MS/MS, there was variation in the amount of feed used for extraction, from 1 to $10 \mathrm{~g}$, due to differences in the analysis target; however, few studies have provided evidence indicating the sample weight that is actually required during extraction $[26,38,40,41]$.

Therefore, in this study, the samples analyzed were divided into 5 and $25 \mathrm{~g}$ amounts during the weighing process to ensure the homogeneity of the sample, and the amount of the detected toxin was compared to determine whether there was a difference. In addition, in order to reduce the influence of matrix effects on quantitation, deuterium- and 13Clabeled compounds were added as internal standards in the assay optimization. Finally, we applied this method in the analysis of 736 feed ingredients and compound feeds. 


\section{Results and Discussion}

\subsection{Optimization of Feed Sample Homogeneity during Sample Preparation}

Because mycotoxins present in feed are distributed in a high concentration in a local range, it is very important to select the minimum possible sample amount to be used in sample preparation while maintaining the homogeneity of the collected sample [42]. MAFRA specifies that samples that have passed through a 20-mesh $(850 \mu \mathrm{m})$ sieve should be used for the analysis of mycotoxins present in feeds [24]. In order to establish the optimal homogeneity of the feed sample, we used $1 \mathrm{~kg}$ samples (mix and grain feed ingredients) containing aflatoxins $B_{1}$ and $B_{2}$ and ochratoxin $A$ to perform a homogeneity test after they were ground to a level of 30 mesh $(600 \mu \mathrm{m})$. All sample preparations were conducted 10 times from $1 \mathrm{~kg}$ of homogenized sample for a final weight of 5 or $25 \mathrm{~g}$. For the mix feed ingredients, levels of aflatoxin $B_{1}$ were found to be $9.13 \pm 0.36$ and $8.90 \pm 0.42 \mu \mathrm{g} / \mathrm{kg}$ in the 5 and $25 \mathrm{~g}$ samples, respectively, and the coefficient of variation $(\mathrm{CV})$ values were all within $5 \%$. Levels of aflatoxin $B_{2}$ were $0.63 \pm 0.07$ and $0.65 \pm 0.13 \mu \mathrm{g} / \mathrm{kg}$ in the 5 and $25 \mathrm{~g}$ samples, respectively, and CV values were $10.80 \%$ and $19.23 \%$, respectively. Levels of ochratoxin A were confirmed to be $2.95 \pm 0.34$ and $2.87 \pm 0.27 \mu \mathrm{g} / \mathrm{kg}$ in the 5 and $25 \mathrm{~g}$ samples, respectively, and CV values were $11.35 \%$ and $9.37 \%$, respectively (Figure $2 \mathrm{a}$ ). Additionally, for grain feed ingredients, levels of aflatoxin $B_{1}$ were verified to be $1.72 \pm 0.19$ and $1.63 \pm 0.16 \mu \mathrm{g} / \mathrm{kg}$ in the 5 and $25 \mathrm{~g}$ samples, respectively, and CV values were $11.30 \%$ and $9.75 \%$, respectively (Figure $2 \mathrm{~b}$ ). We observed that the recovery and CV values of both 5 and $25 \mathrm{~g}$ samples that were analyzed were in accordance with the international standards of AOAC and CODEX [43,44]. These results indicated that efficient analysis was possible when using sample amounts as low as $5 \mathrm{~g}$ during sample preparation.
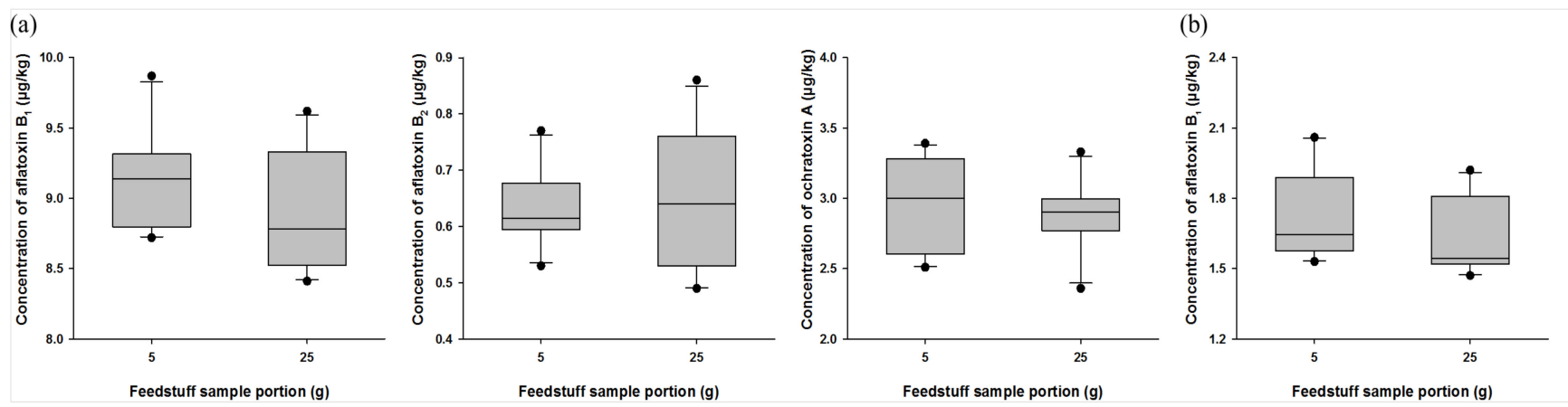

Figure 2. Homogeneity optimization of feed samples: (a) mix feed ingredient; (b) grain feed ingredient during sample preparation. Optimization was conducted using feed samples containing aflatoxins $B_{1}$ and $B_{2}$ and ochratoxin A. All samples were prepared from $1 \mathrm{~kg}$ of homogenized feed sample to final weights of 5 or $25 \mathrm{~g}$, and this preparation was performed 10 times for each sample $(n=10)$.

\subsection{Occurrence of 11 Mycotoxins in Feed Ingredients and Compound Feeds}

The occurrence rates of 11 mycotoxins in 736 feed samples (180 feed ingredients and 556 compound feeds) were determined. In summary, feed ingredients and compound feeds contained mostly FBs, followed by ZEN and DON in terms of mycotoxins. The levels of each mycotoxin found in all feed ingredients and compound feeds are summarized in Table 1. 
Table 1. Levels of 11 mycotoxins in 736 feed ingredients and compound feeds in South Korea in $2020(n=3)$.

\begin{tabular}{|c|c|c|c|c|c|c|c|c|}
\hline \multicolumn{2}{|c|}{ Sample } & $\begin{array}{l}\text { No. of } \\
\text { Samples }\end{array}$ & $\begin{array}{c}\text { No. of } \\
\text { Detected } \\
\text { Samples }{ }^{1} \\
(\%)\end{array}$ & $\begin{array}{c}\text { No. of } \\
\text { Positive } \\
\text { Samples }{ }^{2} \\
(\%)\end{array}$ & $\underset{(\mu \mathrm{g} / \mathrm{kg})}{\operatorname{Minimum}}$ & $\begin{array}{l}\text { Median } \\
(\mu \mathrm{g} / \mathrm{kg})\end{array}$ & $\underset{(\mu \mathrm{g} / \mathrm{kg})}{\text { Maximum }}$ & $\begin{array}{c}\text { Guidance } \\
\text { Limit }^{3} \\
\text { (ppb) }\end{array}$ \\
\hline \multicolumn{9}{|c|}{ Aflatoxin $B_{1}+B_{2}+G_{1}+G_{2}$} \\
\hline \multirow{6}{*}{ Feed ingredients } & Grain & 12 & - & - & - & - & - & 50 \\
\hline & Bran & 25 & - & - & - & - & - & 50 \\
\hline & A. protein ${ }^{4}$ & 27 & - & - & - & - & - & 50 \\
\hline & V. meal ${ }^{5}$ & 40 & $1(2.5)$ & $1(2.5)$ & 159 & 159 & 159 & 50 \\
\hline & Mineral & 13 & - & - & - & - & - & 50 \\
\hline & Mix & 63 & - & - & - & - & - & 50 \\
\hline \multirow{5}{*}{ Compound feeds } & Poultry & 38 & - & - & - & - & - & 10 \\
\hline & Pig & 53 & - & - & - & - & - & 10 \\
\hline & Dairy & 20 & - & - & - & - & - & 10 \\
\hline & Cattle & 42 & - & - & - & - & - & 10 \\
\hline & Pet & 403 & - & - & - & - & - & 10 \\
\hline \multicolumn{9}{|c|}{ Deoxynivalenol } \\
\hline \multirow{6}{*}{ Feed ingredients } & Grain & 12 & $2(16.6)$ & $1(8.3)$ & 575 & 9680 & 18,785 & 10,000 \\
\hline & Bran & 25 & $7(28.0)$ & - & 464 & 1738 & 3478 & 10,000 \\
\hline & A. protein & 27 & - & - & - & - & - & 10,000 \\
\hline & V. meal & 40 & $7(17.5)$ & - & 79 & 821 & 1495 & 10,000 \\
\hline & Mineral & 13 & - & - & - & - & - & 10,000 \\
\hline & Mix & 63 & $5(7.9)$ & - & 54 & 248 & 542 & 10,000 \\
\hline \multirow{5}{*}{ Compound feeds } & Poultry & 38 & $28(73.7)$ & - & 55 & 512 & 2941 & 5000 \\
\hline & Pig & 53 & $42(79.2)$ & $2(3.8)$ & 53 & 328 & 1274 & 900 \\
\hline & Dairy & 20 & $10(50.0)$ & $1(5.0)$ & 138 & 2008 & 2525 & 2000 \\
\hline & Cattle & 42 & $27(64.3)$ & $5(11.9)$ & 74 & 1884 & 13,181 & 2000 \\
\hline & Pet & 403 & $108(26.8)$ & $1(0.2)$ & 51 & 472 & 19,529 & 5000 \\
\hline \multicolumn{9}{|c|}{ Fumonisin $\mathrm{B}_{1}+\mathrm{B}_{2}$} \\
\hline \multirow{6}{*}{ Feed ingredients } & Grain & 12 & $4(33.3)$ & - & 67 & 2054 & 7958 & 60,000 \\
\hline & Bran & 25 & $16(64.0)$ & - & 60 & 2387 & 10,486 & 60,000 \\
\hline & A. protein & 27 & - & - & - & - & - & 60,000 \\
\hline & V. meal & 40 & $16(40.0)$ & - & 43 & 1064 & 2808 & 60,000 \\
\hline & Mineral & 13 & - & - & - & - & - & 60,000 \\
\hline & Mix & 63 & $7(11.1)$ & - & 195 & 757 & 1462 & 60,000 \\
\hline \multirow{5}{*}{ Compound feeds } & Poultry & 38 & $34(89.5)$ & - & 69 & 812 & 5985 & 20,000 \\
\hline & Pig & 53 & 48 (90.6) & - & 80 & 967 & 2059 & 5000 \\
\hline & Dairy & 20 & $19(95.0)$ & - & 127 & 1286 & 3668 & 50,000 \\
\hline & Cattle & 42 & $42(100.0)$ & - & 66 & 2360 & 23,422 & 50,000 \\
\hline & Pet & 403 & $251(62.3)$ & - & 50 & 903 & 3397 & 5000 \\
\hline \multicolumn{9}{|c|}{ Ochratoxin A } \\
\hline \multirow{6}{*}{ Feed ingredients } & Grain & 12 & - & - & - & - & - & 250 \\
\hline & Bran & 25 & $1(4.0)$ & - & 61 & 61 & 61 & 250 \\
\hline & A. protein & 27 & - & - & - & - & - & 250 \\
\hline & V. meal & 40 & - & - & - & - & - & 250 \\
\hline & Mineral & 13 & - & - & - & - & - & 250 \\
\hline & Mix & 63 & - & - & - & - & - & 250 \\
\hline \multirow{5}{*}{ Compound feeds } & Poultry & 38 & $1(2.6)$ & - & 18 & 18 & 18 & 200 \\
\hline & Pig & 53 & - & - & - & - & - & 200 \\
\hline & Dairy & 20 & - & - & - & - & - & 200 \\
\hline & Cattle & 42 & - & - & - & - & - & 200 \\
\hline & Pet & 403 & $1(0.2)$ & - & 11 & 11 & 11 & 200 \\
\hline \multicolumn{9}{|c|}{ T-2 toxin, HT-2 toxin } \\
\hline \multirow{6}{*}{ Feed ingredients } & Grain & 12 & - & - & - & - & - & 500 \\
\hline & Bran & 25 & - & - & - & - & - & 500 \\
\hline & A. protein & 27 & - & - & - & - & - & 500 \\
\hline & V. meal & 40 & $1(2.5)$ & - & 40 & 40 & 40 & 500 \\
\hline & Mineral & 13 & - & - & - & - & - & 500 \\
\hline & Mix & 63 & - & - & - & - & - & 500 \\
\hline
\end{tabular}


Table 1. Cont.

\begin{tabular}{|c|c|c|c|c|c|c|c|c|}
\hline \multicolumn{2}{|c|}{ Sample } & $\begin{array}{c}\text { No. of } \\
\text { Samples }\end{array}$ & $\begin{array}{c}\text { No. of } \\
\text { Detected } \\
\text { Samples } 1 \\
(\%)\end{array}$ & $\begin{array}{c}\text { No. of } \\
\text { Positive } \\
\text { Samples }{ }^{2} \\
(\%)\end{array}$ & $\begin{array}{c}\text { Minimum } \\
(\mu \mathrm{g} / \mathrm{kg})\end{array}$ & $\begin{array}{c}\text { Median } \\
(\mu \mathrm{g} / \mathrm{kg})\end{array}$ & $\begin{array}{c}\text { Maximum } \\
(\mu \mathrm{g} / \mathrm{kg})\end{array}$ & $\begin{array}{c}\text { Guidance } \\
\text { Limit }^{3} \\
(p p b)\end{array}$ \\
\hline \multirow{5}{*}{ Compound feeds } & Poultry & 38 & - & - & - & - & - & 250 \\
\hline & Pig & 53 & - & - & - & - & - & 250 \\
\hline & Dairy & 20 & - & - & - & - & - & 250 \\
\hline & Cattle & 42 & - & - & - & - & - & 250 \\
\hline & Pet & 403 & - & - & - & - & - & 250 \\
\hline \multicolumn{9}{|c|}{ Zearalenone } \\
\hline \multirow{6}{*}{ Feed ingredients } & Grain & 12 & $4(33.3)$ & $1(8.3)$ & 16 & 4552 & 18,113 & 3000 \\
\hline & Bran & 25 & $12(48.0)$ & - & 15 & 523 & 1709 & 3000 \\
\hline & A. protein & 27 & $1(3.7)$ & - & 18 & 18 & 18 & 3000 \\
\hline & V. meal & 40 & $9(22.5)$ & - & 15 & 275 & 931 & 3000 \\
\hline & Mineral & 13 & - & - & - & - & - & 3000 \\
\hline & Mix & 63 & $8(12.7)$ & - & 15 & 61 & 121 & 3000 \\
\hline \multirow{5}{*}{ Compound feeds } & Poultry & 38 & $25(65.8)$ & $1(2.6)$ & 15 & 128 & 1370 & 500 \\
\hline & Pig & 53 & $36(67.9)$ & $2(3.8)$ & 14 & 44 & 143 & 100 \\
\hline & Dairy & 20 & $18(90.0)$ & $2(10.0)$ & 24 & 286 & 2212 & 500 \\
\hline & Cattle & 42 & $37(88.1)$ & 5 (11.9) & 21 & 368 & 18,645 & 500 \\
\hline & Pet & 403 & 130 (32.3) & $1(0.2)$ & 13 & 192 & 17,268 & 1000 \\
\hline
\end{tabular}

${ }^{1}$ Level of mycotoxin higher than LOQ; ${ }^{2}$ level of mycotoxin higher than guidance limit; ${ }^{3}$ guidance for mycotoxin levels in feed according to Ministry of Agriculture, Food and Rural Affairs (MAFRA) from South Korea; ${ }^{4}$ animal protein; ${ }^{5}$ vegetable meal.

\subsubsection{Aflatoxins $\mathrm{B}_{1}, \mathrm{~B}_{2}, \mathrm{G}_{1}$, and $\mathrm{G}_{2}$}

Of the total of 736 samples, AFs were detected in 1 sample, which was a vegetable meal feed. Other than this sample, feed ingredients and compound feeds were not found to be contaminated with AFs. According to the MAFRA guidance from South Korea, MRLs of aflatoxins $B_{1}, B_{2}, G_{1}$, and $G_{2}$ in feeds are defined for the sum of these toxins: MAFRA MRLs of $A F s$ are $50 \mu \mathrm{g} / \mathrm{kg}$ in feed ingredients and $10 \mu \mathrm{g} / \mathrm{kg}$ in compound feeds [24]. In this study, only one positive sample was found to be contaminated with AF, which was present at a level of $159 \mu \mathrm{g} / \mathrm{kg}$ in vegetable meal feed and exceeded the MAFRA MRL of $50 \mu \mathrm{g} / \mathrm{kg}$ in feed ingredients. In addition, the contamination level of aflatoxin $B_{1}$ in vegetable meal feed was $108 \mu \mathrm{g} / \mathrm{kg}$, which is higher than the regulatory limits of $10 \mu \mathrm{g} / \mathrm{kg}$ in China and Japan and $20 \mu \mathrm{g} / \mathrm{kg}$ in the EU, as set by the European Commission (EC) [45-47].

Many studies on AF contamination of feed have been performed worldwide. In South Korea, Kim et al. (2017) analyzed 507 grain feed samples and found AF contamination in $1.0 \%$ of feed samples. The contamination levels ranged from 1 to $12 \mu \mathrm{g} / \mathrm{kg}$ [48]. Additionally, no feed samples showed higher contamination levels than the MAFRA MRL of $50 \mu \mathrm{g} / \mathrm{kg}$ [24]. In another study in South Korea, Kim et al. (2017) monitored 1014 feed samples from 2015 to 2016 and found that AF contamination levels ranged from 2 to $163 \mu \mathrm{g} / \mathrm{kg}$ [49]. One animal protein sample was found to be contaminated with an AF level of $163 \mu \mathrm{g} / \mathrm{kg}$, which exceeded the MAFRA MRL of $50 \mu \mathrm{g} / \mathrm{kg}$ in feed ingredients [24]. In China, Ma et al. (2018) monitored 1569 feed samples from 2016 to 2017 and found aflatoxin $B_{1}$ contamination in $83.3 \%$, and levels ranged from 2 to $68 \mu \mathrm{g} / \mathrm{kg}$ [50]. In a recent similar study, Zhao et al. (2021) measured aflatoxin $B_{1}$ levels in 3507 feed samples collected from 2018 to 2020, and the contamination range was 1-221 $\mu \mathrm{g} / \mathrm{kg}$ [51]. Moreover, aflatoxin $B_{1}$ contamination in 9 feed ingredient samples and 63 compound feed samples exceeded the regulatory limits in China [45,50,51]. In Japan, Nomura et al. (2017) measured aflatoxin $B_{1}$ in 1233 feed samples from 2010 to 2015 and found that $46.0 \%$ of the total feed samples were contaminated with aflatoxin $B_{1}$, with contamination levels ranging from 1 to $24 \mu \mathrm{g} / \mathrm{kg}$ [52]. Monitoring results showed that contamination in five feed samples exceeded the regulatory limit of $20 \mu \mathrm{g} / \mathrm{kg}$ in Japan [46]. Additionally, Uegaki et al. (2018) performed an analysis to determine the levels of aflatoxin $B_{1}$ in 214 feed samples collected from livestock farming establishments in Japan [53]. The contamination range exceeded the Japanese regulatory limit of $1000 \mu \mathrm{g} / \mathrm{kg}$ in one grain feed, and other feeds showed a 
range of 1-22 $\mu \mathrm{g} / \mathrm{kg}$ [46]. In Poland, Grajewski et al. (2012) monitored 1255 feed samples for the occurrence of AFs, and $7.0 \%$ of feed samples were found to be contaminated with AFs. The contamination range was $0-1 \mu \mathrm{g} / \mathrm{kg}$ [54]. In Turkey, Bilal et al. (2014) surveyed 106 feed samples to estimate aflatoxin $B_{1}$ contamination levels, and the contamination range was $1-11 \mu \mathrm{g} / \mathrm{kg}$ [55]. In Spain, Manzanares et al. (2019) performed a similar study and reported that $3.1 \%$ of 288 pig feed samples were contaminated with aflatoxin $\mathrm{B}_{1}$ at levels ranging from 0 to $3 \mu \mathrm{g} / \mathrm{kg}$ [56]. None of the feed samples studied in European countries were found to exceed the EC regulatory limits for feed ingredients and compound feeds (20 and $10 \mu \mathrm{g} / \mathrm{kg}$, respectively) [47,54-56].

The moderate climatic conditions of Europe make it difficult for aflatoxigenic Aspergillus spp. to infiltrate crops. On the other hand, hot and humid climatic conditions in Asia increase the likelihood of exposure to aflatoxin-causing fungi in maize and other crops, and a similar trend was observed in this study. A study by Dorninger et al. also reported that hot and humid weather conditions affect AF contamination [57].

\subsubsection{Deoxynivalenol}

DON was detected in one-third (236) of the total 736 samples. DON was most frequently detected in pig feed (79.2\%), and levels ranged from 53 to $1274 \mu \mathrm{g} / \mathrm{kg}$. The rates of DON contamination in feed ingredients were $16.6 \%, 28.0 \%, 17.5 \%$, and $7.9 \%$ in grain, bran, vegetable meal, and mix feeds, respectively. By contrast, animal protein and mineral feeds were not contaminated with DON. In addition, over half of the collected compound feed samples showed DON contamination. The DON contamination rates in compound feeds were $73.7 \%, 79.2 \%, 50.0 \%, 64.3 \%$, and $26.8 \%$ in poultry, pig, dairy, cattle, and pet feeds, respectively. The occurrence of DON in 736 feed samples levels ranged from 51 to $19,529 \mu \mathrm{g} / \mathrm{kg}$. The maximum level was $19,529 \mu \mathrm{g} / \mathrm{kg}$ in pet feed, followed by $18,785 \mu \mathrm{g} / \mathrm{kg}$ in grain feed. The median level was $9680 \mu \mathrm{g} / \mathrm{kg}$ in grain feed, followed by $2008 \mu \mathrm{g} / \mathrm{kg}$ in dairy feed.

According to the MAFRA guidance from South Korea, the recommended limits of DON are $5000 \mu \mathrm{g} / \mathrm{kg}$ in feed ingredients and, among compound feeds, $5000 \mu \mathrm{g} / \mathrm{kg}$ in poultry and pet feeds, $2000 \mu \mathrm{g} / \mathrm{kg}$ in dairy and cattle feeds, and $900 \mu \mathrm{g} / \mathrm{kg}$ in pig feed [24]. A total of 10 positive samples contained DON levels above the limits recommended by MAFRA; the 10 samples comprised 1 feed ingredient (grain feed) and 9 compound feeds, including 2 pig feeds, 1 dairy feed, 5 cattle feeds, and 1 pet feed. Notably, in a total of five cattle feed samples, which account for $11.9 \%$ of all cattle feed samples, the contamination range of DON was 2075-13,181 $\mu \mathrm{g} / \mathrm{kg}$, which exceeded the MAFRA recommended limit of $2000 \mu \mathrm{g} / \mathrm{kg}$.

The measured values were compared with regulatory or guidance limits in other countries, and the results showed that one grain feed sample was higher than the regulatory limit of $5000 \mu \mathrm{g} / \mathrm{kg}$ established by China and the EC guidance limit of $8000 \mu \mathrm{g} / \mathrm{kg}[45,58]$. Four grain feed samples exceeded the regulatory limit of $1000 \mu \mathrm{g} / \mathrm{kg}$ in Japan [46]. Furthermore, two pig feed samples exceeded the regulatory limit of $1000 \mu \mathrm{g} / \mathrm{kg}$ in China and Japan and the EC guidance limit of $900 \mu \mathrm{g} / \mathrm{kg}[45,46]$. In addition, three cattle feed samples exceeded the regulatory limits of $3000 \mu \mathrm{g} / \mathrm{kg}$ in China, $4000 \mu \mathrm{g} / \mathrm{kg}$ in Japan, and the EC guidance limit of $5000 \mu \mathrm{g} / \mathrm{kg}[45,46,58]$. By contrast, three poultry and three dairy feed samples that did not exceed the MARFA recommended limit of $5000 \mu \mathrm{g} / \mathrm{kg}$ had higher contamination levels than the regulatory limit of $1000 \mu \mathrm{g} / \mathrm{kg}$ in Japan [46].

Many studies have been conducted worldwide on the level of DON contamination in feeds. In a previous study in South Korea, Park et al. (2018) monitored 653 feed samples collected from 2009 to 2016 and found that 79.7\% had DON contamination, with ranging from 1 to $8480 \mu \mathrm{g} / \mathrm{kg}$ [59]. The maximum level of DON was identified in bran feed and did not exceed the MAFRA recommended limit of 10,000 $\mu \mathrm{g} / \mathrm{kg}$ [24]. In another previous study, the contamination level of DON tended to be lower than the levels detected in this study. In China, Wu et al. (2016) detected DON in $93.9 \%$ of 560 feed samples that were collected from 2013 to 2015. The contamination levels ranged from 349 to 
$4403 \mu \mathrm{g} / \mathrm{kg}$ [60]. Ma et al. (2018) monitored 1569 feed samples from 2016 to 2017 and found DON contamination in $74.5 \%$, with levels ranging from 450 to $12,633 \mu \mathrm{g} / \mathrm{kg}$ [50]. In a recent report, Zhao et al. (2021) analyzed 3507 feed samples collected from 2018 to 2020 and found DON contamination in $96.4 \%$, with contamination levels ranging from 458 to $9186 \mu \mathrm{g} / \mathrm{kg}$ [51]. In Japan, Uegaki et al. (2018) analyzed 214 feed samples. The DON contamination rate in feeds was $64.0 \%$, and 11 feed samples exceeded the regulatory limit of $1000 \mu \mathrm{g} / \mathrm{kg}$ in Japan [46,53]. In Portugal, Almeida et al. (2011) analyzed 277 pig feed samples and confirmed that $16.9 \%$ of total feeds were contaminated with DON in a range of 100-864 $\mu \mathrm{g} / \mathrm{kg}$ [61]. Additionally, no pig feed samples were found to have contamination levels higher than the EC guidance limit of $900 \mu \mathrm{g} / \mathrm{kg}$ [58]. In Poland, Grajewski et al. (2012) monitored 1255 feed samples collected from 2006 to 2009 and found DON contamination in $88.0 \%$ of feeds. The contamination levels ranged from 409 to $7356 \mu \mathrm{g} / \mathrm{kg}$ [54]. The concentration of DON did not exceed the EC guidance limit of $8000 \mu \mathrm{g} / \mathrm{kg}$ for grain feeds [58]. In Turkey, Bilal et al. (2014) measured the levels of DON in 106 feed samples. The contamination rate was $43.4 \%$, and levels ranged from 37 to $4770 \mu \mathrm{g} / \mathrm{kg}$ [55]. The highest contamination level was identified in corn feed, but it did not exceed the EC guidance limit of $8000 \mu \mathrm{g} / \mathrm{kg}$ [58].

High rainfall and warm temperatures during the growing season of wheat or corn have been shown to increase the occurrence of DON. High rainfall during the growing season can promote contamination with Fusarium spp. in corn or wheat, while continued rainfall during harvest provides adequate moisture to sustain fungal growth and mycotoxin production within the grain. In particular, higher DON concentrations occurred in East Asia with heavy rainfall in August and September compared to those in European countries [57].

\subsubsection{Fumonisins $B_{1}$ and $B_{2}$}

FBs were detected in more than half (437) of the total of 736 samples. FBs were most frequently detected in cattle feed (100.0\%), and the levels ranged from 66 to $23,422 \mu \mathrm{g} / \mathrm{kg}$. The FB contamination rates in feed ingredients were $33.3 \%, 64.0 \%, 40.0 \%$, and $11.1 \%$ in grain, bran, vegetable meal, and mix feeds, respectively. By contrast, animal protein and mineral feeds were not contaminated with FBs. Over half of the collected compound feed samples showed FB contamination with $89.5 \%, 90.6 \%, 95.0 \%, 100.0 \%$, and $62.3 \%$ in poultry, pig, dairy, cattle, and pet feeds, respectively. These results showed that the occurrence of FBs in feed ingredients and compound feeds was similar to that of DON. The levels of FBs in 736 feed samples ranged from 43 to $23,422 \mu \mathrm{g} / \mathrm{kg}$. The maximum level was $23,422 \mu \mathrm{g} / \mathrm{kg}$ in cattle feed, followed by $10,486 \mu \mathrm{g} / \mathrm{kg}$ in bran feed. The median level was $2387 \mu \mathrm{g} / \mathrm{kg}$ in bran feed, followed by $2360 \mu \mathrm{g} / \mathrm{kg}$ in cattle feed.

According to the MAFRA guidance from South Korea, the recommended limits of fumonisin $B_{1}$ and $B_{2}$ in feeds are defined for the sum of these toxins. The MAFRA recommended limit of FBs in feed ingredients is $60,000 \mu \mathrm{g} / \mathrm{kg}$; in compound feeds, the recommended limits are $50,000 \mu \mathrm{g} / \mathrm{kg}$ in dairy and cattle feeds, $20,000 \mu \mathrm{g} / \mathrm{kg}$ in poultry feed, and $5000 \mu \mathrm{g} / \mathrm{kg}$ in pig and pet feeds [24]. In contrast to the 10 positive samples exceeding MAFRA-recommended limits of DON, no FB-positive samples that exceeded the MAFRA recommended limits in feed ingredients and compound feeds were identified. Additionally, none of the analyzed feed samples were found to have FB contamination levels exceeding the EC guidance limit [58].

In a previous report in South Korea, Kim et al. (2014) analyzed 180 feed samples for the occurrence of FBs, and $91.7 \%$ were found to be contaminated with FBs [62]. The contamination range was 37-12,823 $\mu \mathrm{g} / \mathrm{kg}$, and the contamination level of FBs in one pig feed sample exceeded the MAFRA recommended limit of $5000 \mu \mathrm{g} / \mathrm{kg}$ [24]. Additionally, Park et al. (2017) monitored 535 feed samples collected from 2011 to 2016 to estimate FB contamination levels [63]. The contamination range was $15-15,098 \mu \mathrm{g} / \mathrm{kg}$, and seven pig feed samples exceeded the MAFRA-recommended limit of $5000 \mu \mathrm{g} / \mathrm{kg}$ [24]. In Poland, Grajewski et al. (2012) examined FB contamination levels in 1255 feed samples and showed that the contamination rate and level were $78.0 \%$ and $10-9409 \mu \mathrm{g} / \mathrm{kg}$, respectively [54]. The maximum 
level of FBs was identified in grain feeds, which did not exceed the EC guidance limit of $60,000 \mu \mathrm{g} / \mathrm{kg}$ [58]. In Spain, Manzanares et al. (2019) analyzed 288 pig feed samples, of which $79.8 \%$ were contaminated with FBs [56] in the range of 4-3959 $\mu \mathrm{g} / \mathrm{kg}$. No feed samples were found to exceed the EC guidance limit of $5000 \mu \mathrm{g} / \mathrm{kg}$ [58].

FB contamination is closely related to high temperatures and high precipitation during the growing season of grains. Thus, regions with warm, dry climates such as America and East Asia have particularly high levels of contamination. Consequently, previous studies have shown that FB contamination levels in South Korea, China, and Japan are higher than those in European countries [57].

\subsubsection{Ochratoxin A}

Of the total 736 samples, OTA was detected in three samples, which were bran, poultry, and pet feeds. Except for the above three feed samples, OTA was not found in the other feed ingredients and compound feeds that were examined. According to the MAFRA guidance from South Korea, the MRLs of OTA are $250 \mu \mathrm{g} / \mathrm{kg}$ in feed ingredients and $200 \mu \mathrm{g} / \mathrm{kg}$ in compound feeds [24]. In this study, we found that bran, poultry, and pet feeds were contaminated with OTA levels of 61,18 , and $11 \mu \mathrm{g} / \mathrm{kg}$, respectively, which did not exceed the MAFRA MRL.

In a previous report in South Korea, Kim et al. (2017) monitored 507 grain feed samples and identified 1 that was contaminated with OTA at a level of $0.5 \mu \mathrm{g} / \mathrm{kg}$ [48]. A similar study was conducted by Kim et al. (2017) to determine the levels of OTA in 1014 feed samples collected from 2015 to 2016 in South Korea [49], where the contamination range was $2-45 \mu \mathrm{g} / \mathrm{kg}$, which did not exceed the MAFRA MRL of $200 \mu \mathrm{g} / \mathrm{kg}$ [24]. In Portugal, Almeida et al. (2011) examined 277 pig feed samples and confirmed that $7.6 \%$ of total feeds were contaminated with OTA in a range from 2 to $7 \mu \mathrm{g} / \mathrm{kg}$ [61]. In Poland, Grajewski et al. (2012) performed a similar study and reported that $30.8 \%$ of 1255 feed samples were contaminated with OTA, with contamination levels ranging from 1 to $760 \mu \mathrm{g} / \mathrm{kg}$ [54]. Among these 1255 feed samples, 2 feed ingredients and 4 pig feed samples were found to exceed the EC guidance limits of 250 and $50 \mu \mathrm{g} / \mathrm{kg}$, respectively [58]. Although the levels of OTA occurrence in South Korea are low compared to other European countries, continuous management is required.

\subsubsection{T-2 and HT-2 Toxins}

Of the total of 736 samples, T-2 and HT-2 toxins were detected in 1 sample, which was a vegetable meal feed. The remaining samples were not found to be contaminated with T-2 and HT-2 toxins. According to the MAFRA guidance from South Korea, the recommended limits for the overall combined level of T-2 and HT-2 toxins in are defined individually for their use as feed ingredient of in compound feeds; the MAFRA recommended limits of T-2 and HT-2 toxins are $500 \mu \mathrm{g} / \mathrm{kg}$ for feed ingredients and $250 \mu \mathrm{g} / \mathrm{kg}$ for compound feeds [24]. In this study, only vegetable meal feed was found to be contaminated with T-2 and HT-2 toxins; the T-2 and HT-2 toxin level was $40 \mu \mathrm{g} / \mathrm{kg}$, which did not exceed the MAFRA recommended limit or the EC guidance limit of $500 \mu \mathrm{g} / \mathrm{kg}$ in feed ingredients [24,58].

In a previous report in South Korea, Ok et al. (2013) carried out an analysis on T-2 and HT-2 toxin levels in 214 grain feed samples obtained from grocery markets, and found a contamination range of 6-207 $\mu \mathrm{g} / \mathrm{kg}$ [64]. In a similar study, Kim et al. (2017) analyzed 507 grain feed samples, and $2.0 \%$ were found to be contaminated with T-2 and HT-2 toxins. The contamination range was $4-14 \mu \mathrm{g} / \mathrm{kg}$ [48]. In Poland, Grajewski et al. (2012) monitored T-2 and HT-2 toxins in 1255 feed samples from 2006 to 2009 , and found that $26.0 \%$ of the total feed samples were contaminated with T-2 and HT-2 toxins, and the contamination levels ranged from 1 to $289 \mu \mathrm{g} / \mathrm{kg}$ [54]. In Spain, Manzanares et al. (2019) analyzed 288 pig feed samples and found T-2 and HT-2 toxin contamination in $96.4 \%$. The contamination levels ranged from 458 to $9186 \mu \mathrm{g} / \mathrm{kg}$ [56]. Contamination levels of T-2 and HT-2 toxins in our study were found to be lower than those of previous reports. 


\subsubsection{Zearalenone}

ZEN was detected in about $38.0 \%$ (280) of the total of 736 feed samples. ZEN was most frequently detected in dairy feed (90.0\%), and levels ranged from 24 to $2212 \mu \mathrm{g} / \mathrm{kg}$. The ZEN contamination rates in feed ingredients were $33.3 \%, 48.0 \%, 3.7 \%, 22.5 \%$, and $12.7 \%$ in grain, bran, animal protein, vegetable meal, and mix feeds, respectively. By contrast, the mineral feed was not contaminated with ZEN. In addition, ZEN contamination was detected in over half of the collected compound feed samples. The contamination rates of ZEN in compound feeds were $65.8 \%, 67.9 \%, 90.0 \%, 88.1 \%$, and $32.3 \%$ in poultry, pig, dairy, cattle, and pet feeds, respectively. The ZEN levels ranged from 13 to $18,645 \mu \mathrm{g} / \mathrm{kg}$ among the 736 feed samples. The maximum level was $18,645 \mu \mathrm{g} / \mathrm{kg}$ in cattle feed, followed by $18,113 \mu \mathrm{g} / \mathrm{kg}$ in grain feed. The median level was $4552 \mu \mathrm{g} / \mathrm{kg}$ in grain feed, followed by $523 \mu \mathrm{g} / \mathrm{kg}$ in bran feed.

According to the MAFRA guidance from South Korea, the recommended limits of ZEN are $3000 \mu \mathrm{g} / \mathrm{kg}$ in feed ingredients, and among compound feeds, $500 \mu \mathrm{g} / \mathrm{kg}$ in poultry, dairy, and pet feeds; $100 \mu \mathrm{g} / \mathrm{kg}$ in pig feed; and $1000 \mu \mathrm{g} / \mathrm{kg}$ in pet feed [24]. A total of 12 positive samples were contaminated with ZEN levels above the MAFRA recommended limits; the 12 samples comprised 1 feed ingredient (grain feed) and 11 compound feeds, including 1 poultry feed, 2 pig feeds, 2 dairy feeds, 5 cattle feeds, and 1 pet feed. Notably, in a total of five cattle feed samples, which accounted for $11.9 \%$ of all cattle feed samples, the contamination range of ZEN was $21-18,645 \mu \mathrm{g} / \mathrm{kg}$, which exceeded the MAFRA recommended limit of $500 \mu \mathrm{g} / \mathrm{kg}$.

The measured values were compared with regulatory or guidance limits in other countries, and the results showed that one grain feed sample was higher than the EC guidance limit of $2000 \mu \mathrm{g} / \mathrm{kg}$ [58]. Five grain and one poultry feed sample exceeded the regulatory limit of $1000 \mu \mathrm{g} / \mathrm{kg}$ in China and Japan [45,46]. In addition, two pig feed samples exceeded the EC guidance limit of $100 \mu \mathrm{g} / \mathrm{kg}$ [58]. Furthermore, two dairy and five cattle feed samples had higher contamination levels than the Chinese regulatory limit and the EC guidance limit of $500 \mu \mathrm{g} / \mathrm{kg}$, respectively $[45,58]$.

Many studies on ZEN contamination in feeds have been performed worldwide. In a previous study in South Korea, Kim et al. (2014) analyzed 180 feed samples and found ZEN contamination in $62.8 \%$ of all feeds [62]. The contamination levels ranged from 8 to $413 \mu \mathrm{g} / \mathrm{kg}$, and several pig feed samples showed higher contamination levels than the MAFRA-recommended limit of $100 \mu \mathrm{g} / \mathrm{kg}$ [24]. In a similar study, Kim et al. (2017) conducted an analysis to determine the levels of ZEN in 507 grain feed samples [48]. The contamination range was 1-313 $\mu \mathrm{g} / \mathrm{kg}$, which did not exceed the MAFRA-recommended limit of $3000 \mu \mathrm{g} / \mathrm{kg}$ [24]. Chang et al. (2017) confirmed that $86.7 \%$ of 653 feed samples collected from 2009 to 2016 were contaminated with ZEN, and the contamination levels ranged from 1 to $1330 \mu \mathrm{g} / \mathrm{kg}$ [65]. Two cattle and two pig feed samples exceeded the MAFRArecommended limits of 500 and $100 \mu \mathrm{g} / \mathrm{kg}$, respectively [24]. In China, Ma et al. (2018) monitored ZEN levels in 1569 feed samples collected from 2016 to 2017. They found ZEN contamination in $88.0 \%$ of samples, and the contamination range was $2-1363 \mu \mathrm{g} / \mathrm{kg}$ [50]. Zhao et al. (2021) monitored 3507 feed samples from 2018 to 2020 and found ZEN contamination in $96.9 \%$, and levels ranged from 31 to $1599 \mu \mathrm{g} / \mathrm{kg}$ [51]. Moreover, ZEN contamination in 71 feed ingredients and 37 compound feeds exceeded the Chinese regulatory limits of 500 and $250 \mu \mathrm{g} / \mathrm{kg}$, respectively [45,50,51]. In Japan, Uegaki et al. (2018) measured the levels of ZEN in 214 feed samples. The contamination rate was $49.0 \%$, and levels ranged from 46 to $1200 \mu \mathrm{g} / \mathrm{kg}$ [53]. The highest contamination was identified in grass feed samples, two of which exceeded the regulatory limit of $1000 \mu \mathrm{g} / \mathrm{kg}$ in Japan [46]. In Portugal, Almeida et al. (2011) monitored ZEN in 404 pig feed samples and found that $19.1 \%$ of the total feed samples were contaminated with ZEN, and the contamination levels ranged from 5 to $73 \mu \mathrm{g} / \mathrm{kg}$ [61]. In Turkey, Bilal et al. (2014) examined 106 feed samples and confirmed that $43.4 \%$ of total feeds were contaminated with ZEN in a range from 3 to $97 \mu \mathrm{g} / \mathrm{kg}$ [55]. Additionally, none of the studied feed samples had levels of ZEN contamination that exceeded the EC guidance limits [58]. In Spain, Manzanares et al. (2019) 
analyzed 228 pig feed samples and confirmed that $7.0 \%$ of total feeds were contaminated with ZEN in a range from 101 to $956 \mu \mathrm{g} / \mathrm{kg}$ [56]. Additionally, six pig feed samples showed higher contamination levels than the EC guidance limit of $100 \mu \mathrm{g} / \mathrm{kg}$ [58].

The increase in the occurrence of ZEN, one of the well-known toxins produced by Fusarium spp. in addition to DON, was influenced by high rainfall and warm temperatures during the growing season of wheat or corn. High rainfall during the growing season can promote contamination with Fusarium spp. in corn or wheat, while continued rainfall during harvest can provide adequate moisture for sustained fungal growth and mycotoxin production within the grain. In particular, higher ZEN concentrations occurred in East Asia with heavy rainfall in August and September compared to values reported in previous studies in European countries [57].

\subsection{Co-Occurrence of Mycotoxins in Feed Ingredients and Compound Feeds}

The co-occurrence of DON, FBs, OTA, T-2 toxin, HT-2 toxin, and ZEN in feed samples is shown in Table 2. Of the total samples, $36.5 \%$ were not contaminated with any mycotoxins, $19.7 \%$ were contaminated with a single mycotoxin, and $43.8 \%$ were simultaneously contaminated with two or more mycotoxins, and the occurrence rates were $9.6-48.0 \%$ in feed ingredients and $39.7-95.2 \%$ in compound feeds. These results are supported by previous studies showing that compound feeds are particularly susceptible to multiple contaminations because they typically contain several raw materials [8]. The co-occurrence of DON, ZEN, and FBs, which are known to be produced by the genus Fusarium, was detected most frequently in compound feeds in particular combinations, in the following order of decreasing prevalence: $\mathrm{DON}+\mathrm{FBs}+\mathrm{ZEN}(15.9-62.3 \%)>\mathrm{ZEN}+\mathrm{FBs}(5.7-45.0 \%)>\mathrm{DON}+\mathrm{FBs}(5.0-13.2 \%)$. In particular, nine samples (one grain, one pig, one dairy, five cattle, and one pet feed) were simultaneously contaminated by DON+ZEN+FBs, and DON and ZEN exceeded the limits suggested by MARFA [24]. The concentration ranges of DON and ZEN were 1274-19,529 and 143-18,645 $\mu \mathrm{g} / \mathrm{kg}$, respectively. Previous studies have shown that co-contamination with DON and ZEN resulted in an additive or synergistic risk or antagonistic effects in animals such as pigs, rats, and mice [57]. A study of the co-occurrence of ZEN and DON showed that the toxins may induce mitochondrial apoptosis processes in humans, as indicated in a cytotoxicity assay using a human colon cancer cell line (HCT116) [66]. In addition, in human granulocyte hematopoietic progenitor cells, DON and ZEN were reported to have an additive effect on apoptosis resulting from the stimulation of caspase- 3 activity [67]. In addition, it was suggested that when simultaneously contaminated by aflatoxin b1, DON, and ZEN, mouse and rat liver cells may have a higher hepatotoxic than individual contamination $[68,69]$. These results suggest that the toxicity of co-contaminating mycotoxins may not be possible to predict based only on the mechanisms of the individual toxins [70]. The co-occurrence of mycotoxins is important in that mycotoxigenic fungi are capable of producing more than one mycotoxin, and are influenced by the surrounding environment and the multiple raw materials found in feeds [62,71,72]. Thus, studying the contamination of a single mycotoxin cannot provide sufficient information about the risks associated with each feed [73]. Furthermore, simultaneous contamination with mycotoxins has been shown to have greater negative effects on health and productivity than with single mycotoxins [74]. The co-occurrence of mycotoxins in feeds has been consistently reported in many countries $[50,51,61,75,76]$. However, current safety regulations do not consider the toxic potential of co-occurring mycotoxins, so it is necessary to establish strict management standards for the co-occurrence of mycotoxins, and to continuously monitor them in feeds. 
Table 2. Co-occurrence of 11 mycotoxins in 736 feed ingredients and compound feeds.

\begin{tabular}{|c|c|c|c|c|c|c|c|c|c|c|}
\hline \multicolumn{2}{|c|}{ Sample } & \multirow{2}{*}{$\begin{array}{c}\begin{array}{c}\text { No. of } \\
\text { Samples }\end{array} \\
12\end{array}$} & \multirow{2}{*}{$\begin{array}{c}\begin{array}{c}\text { No. of } \\
\text { Co-Occurrence } \\
\text { Samples } \\
(\%)\end{array} \\
2(16.7)\end{array}$} & \multirow{2}{*}{$\begin{array}{c}\mathrm{DON}^{1}+ \\
\mathrm{FBs}^{2} \\
(\%)\end{array}$} & \multirow{2}{*}{$\begin{array}{c}\text { DON + } \\
\mathrm{ZEN}^{3} \\
(\%) \\
-\end{array}$} & \multirow{2}{*}{$\begin{array}{c}\text { FBs }+ \\
\text { OTA } \\
(\%)\end{array}$} & \multirow{2}{*}{$\begin{array}{c}\text { FBs + } \\
\begin{array}{c}\text { T-2/HT-2 } \\
(\%)\end{array} \\
-\end{array}$} & \multirow{2}{*}{$\begin{array}{c}\begin{array}{c}\text { FBs + } \\
\text { ZEN } \\
(\%)\end{array} \\
1(8.3)\end{array}$} & \multirow{2}{*}{$\begin{array}{c}\text { DON + } \\
\text { FBs + } \\
\text { OTA } \\
(\%) \\
-\end{array}$} & \multirow{2}{*}{$\begin{array}{c}\text { DON + } \\
\text { FBs + } \\
\begin{array}{c}\text { ZEN } \\
(\%)\end{array} \\
1(8.3)\end{array}$} \\
\hline \multirow{6}{*}{$\begin{array}{c}\text { Feed } \\
\text { ingredients }\end{array}$} & Grain & & & & & & & & & \\
\hline & Bran & 25 & $12(48.0)$ & $1(4.0)$ & - & - & - & $5(20.0)$ & - & $6(24.0)$ \\
\hline & $\begin{array}{l}\text { Animal } \\
\text { protein }\end{array}$ & 27 & - & - & - & - & - & - & - & - \\
\hline & $\begin{array}{l}\text { Vegetable } \\
\text { meal }\end{array}$ & 40 & $10(25.0)$ & - & - & - & $1(2.5)$ & $3(7.5)$ & - & $6(15.0)$ \\
\hline & Mineral & 13 & - & - & - & - & - & - & - & - \\
\hline & Mix & 63 & $6(9.5)$ & $1(1.6)$ & - & - & - & $3(4.8)$ & - & $2(3.2)$ \\
\hline \multirow{5}{*}{$\begin{array}{l}\text { Compound } \\
\text { feeds }\end{array}$} & Poultry & 38 & $31(81.6)$ & $5(13.2)$ & - & - & - & $3(7.9)$ & $1(2.6)$ & $22(57.9)$ \\
\hline & Pig & 53 & $42(79.2)$ & $6(11.3)$ & - & - & - & $3(5.7)$ & - & $33(62.3)$ \\
\hline & Dairy & 20 & $19(95.0)$ & $1(5.3)$ & - & - & - & $9(45.0)$ & - & $9(45.0)$ \\
\hline & Cattle & 42 & $40(95.2)$ & $3(7.1)$ & - & - & - & $13(31.0)$ & - & $24(57.1)$ \\
\hline & Pet & 403 & $160(39.7)$ & $35(8.7)$ & $3(0.7)$ & $1(0.2)$ & - & 57 (14.1) & - & $64(15.9)$ \\
\hline
\end{tabular}

${ }^{1}$ DON, deoxynivalenol; ${ }^{2} \mathrm{FBs}$, fumonisin $\mathrm{B}_{1}$ and $\mathrm{B}_{2} ;{ }^{3} \mathrm{ZEN}$, zearalenone; ${ }^{4}$ OTA, ochratoxin A.

\section{Conclusions}

In this study, the QuEChERS-based LC-MS/MS method was optimized to simultaneously quantify 11 mycotoxins contained in feeds, whereby deuterium- and 13C-labeled compounds were used as internal standards. In addition, it was confirmed that there was no significant difference in the amount of mycotoxin detected when the weight of corn feed differed in the pretreatment stage. This optimized method was applied to 736 samples of feed ingredients and compound feeds commonly consumed in South Korea. The results showed that of the 11 examined mycotoxins, DON, FBs, and ZEN were most frequently detected in feeds. Among them, DON and ZEN were found to exceed the guidance limits set by MAFRA in 10 and 12 samples, respectively. Most of the positive samples were identified in compound feeds. Therefore, it is necessary to more strictly manage the regulation and guideline levels of contamination with mycotoxins such as DON, FBs, and ZEN in compound feeds in South Korea. In addition, these results suggested the need for continuous monitoring of mycotoxins in feed ingredients and compound feeds.

\section{Materials and Methods}

\subsection{Chemical and Reagents}

All mycotoxin standards and internal standards (ISs) were provided by Sigma-Aldrich (St. Louis, MO, USA) and Cfm Oskar Tropitzsch GmbH (Marktredwitz, Germany). Acetonitrile $(\mathrm{ACN})$, methanol $(\mathrm{MeOH})$, and water were purchased from Merck (Darmstadt, Germany). All solvents used in the analysis were LC-MS grade. Purified water was obtained using a Milli-Q system (Millipore, Bedford, MA, USA). Ammonium formate was obtained from Sigma-Aldrich (St. Louis, MO, USA). Formic acid was supplied by Fisher Scientific (Pittsburgh, PA, USA). Bondesil primary secondary amine (PSA) and octadecylsilane (C18) were provided by Biotage (Uppsala, Sweden). QuEChERS salt mixture containing $4 \mathrm{~g}$ of $\mathrm{MgSO}_{4}$ and $1 \mathrm{~g}$ of $\mathrm{NaCl}$ was purchased from BEKOlut $\mathrm{GmbH} \& \mathrm{Co}$. KG (Hauptstuhl, Germany).

\subsection{Samples}

For mycotoxin monitoring in feeds commonly used in South Korea, a total of 736 feed samples (180 feed ingredients and 556 compound feeds) were randomly obtained from feed factories and markets in various locations in South Korea. All feed samples were ground using an SM 300 cutting mill (Retsch, Germany) to a particle size $<4 \mathrm{~mm}$ and stored in the freezer at $-20^{\circ} \mathrm{C}$.

\subsection{Preparation of Standard Solutions}

Individual stock solutions of mycotoxins and IS were dissolved in $\mathrm{ACN}$ or $\mathrm{MeOH}$. Working standard solutions were prepared with ACN for the calibration curve, constructed at each concentration based on MAFRA from South Korea [24]. All solutions were placed in amber glass vials and stored in the freezer at $-20^{\circ} \mathrm{C}$. 


\subsection{Calibration Curve}

Internal standard calibration curves were plotted with five points for each mycotoxin based on MAFRA from South Korea. The calibration ranges of 11 mycotoxins were evaluated as $0.5-25 \mathrm{ng} / \mathrm{mL}$ for aflatoxins $B_{1}, B_{2}, G_{1}$, and $G_{2} ; 10-500 \mathrm{ng} / \mathrm{mL}$ for deoxynivalenol, fumonisins $B_{1}$ and $B_{2}, T-2$ toxin, and HT-2 toxin; $2-100 \mathrm{ng} / \mathrm{mL}$ for ochratoxin $A$; and $2.5-125 \mathrm{ng} / \mathrm{mL}$ for zearalenone [32]. An internal standard (IS) labeled with isotope or deuterium was used for quantification. The analysis was performed under established LC-MS/MS conditions, and the calibration curve was prepared in the form of $y=a x+b$ (y: peak area; $\mathrm{x}$ : concentration).

\subsection{Sample Preparation Using Optimized QuEChERS Method}

Prior to their extraction, $1 \mathrm{~kg}$ feed samples with representative properties were ground and homogenized using a cutting mill. About $5 \mathrm{~g}$ of each ground sample was extracted with $10 \mathrm{~mL}$ of acetonitrile and $10 \mathrm{~mL}$ of water with $10 \%$ formic acid in a homogenizer at $4000 \mathrm{rpm}$ for $30 \mathrm{~min}$. After extraction, $4 \mathrm{~g}$ of $\mathrm{MgSO}_{4}$ and $1 \mathrm{~g}$ of $\mathrm{NaCl}$ were added to the samples, and solutions were shaken at $4000 \mathrm{rpm}$ for $1 \mathrm{~min}$. Extracted samples were centrifuged at $4000 \mathrm{rpm}$ for $10 \mathrm{~min}$. For sample clean up, $1 \mathrm{~mL}$ of the supernatant obtained from centrifugation was added to a $1.5 \mathrm{~mL}$ centrifuge tube containing $25 \mathrm{mg}$ of $\mathrm{C} 18$ and $25 \mathrm{mg}$ of PSA and shaken at 10,000 rpm for $5 \mathrm{~min}$. After centrifugation, $400 \mu \mathrm{L}$ aliquots of supernatant were transferred into a $1.5 \mathrm{~mL}$ centrifuge tube and mixed with $500 \mu \mathrm{L}$ of distilled water and $100 \mu \mathrm{L}$ of $\mathrm{ACN}$, which was stored in the refrigerator at $4{ }^{\circ} \mathrm{C}$ for $30 \mathrm{~min}$. All samples were filtered using a $0.2 \mu \mathrm{m}$ polytetrafluoroethylene (PTFE) syringe filter and stored in plastic vials. The sample extracts were analyzed by liquid chromatographytandem mass spectrometry (LC-MS/MS) [32]. All sample preparations were performed in triplicate. The analytical flow of the optimized QuEChERS extraction method for the analysis of mycotoxins in feed samples is shown in Figure 3.

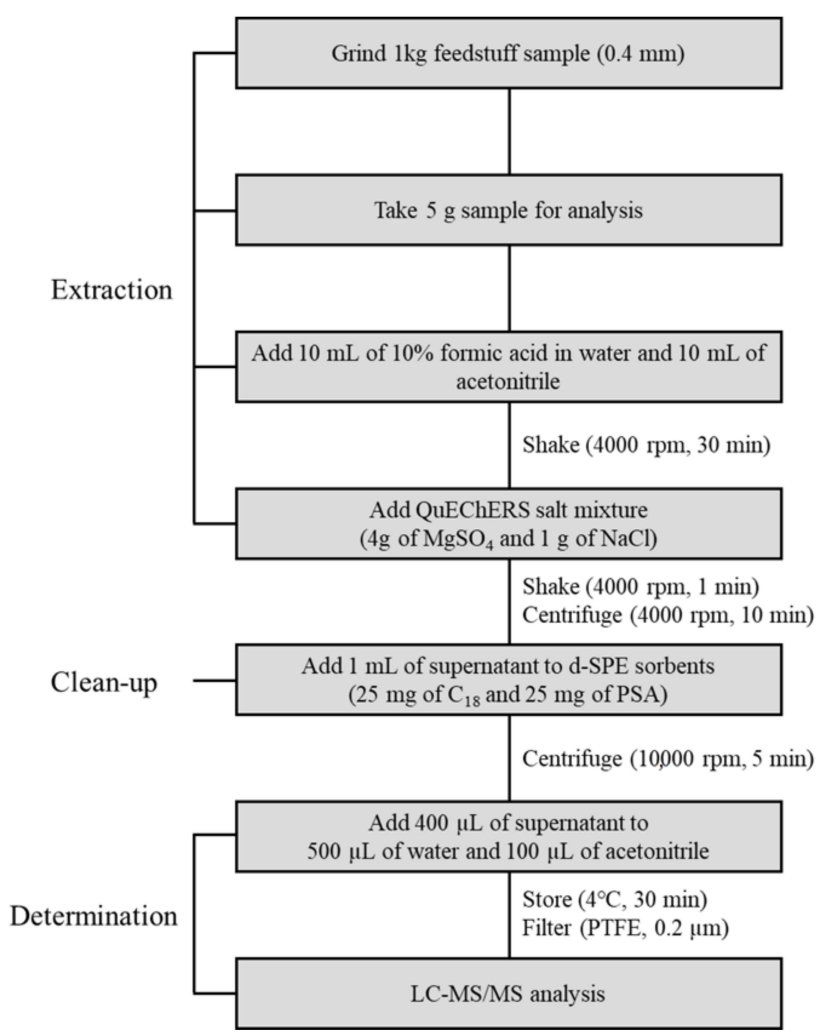

Figure 3. Analytical flow of the optimized QuEChERS method for the analysis of mycotoxins in feed samples. 


\subsection{LC-MS/MS Analysis}

The determination of 11 mycotoxins in feed ingredients and compound feeds was performed in accordance with a previous report with slight modifications [32]. All mycotoxins and the internal standards were analyzed on a Shimadzu LC-MS 8050 triple-quadrupole mass spectrometer equipped with a Nexera X2 ultra-high-performance liquid chromatography system (Shimadzu, Kyoto, Japan) coupled with an electrospray ionization (ESI) interface. Chromatographic separation was carried out in an Imtakt Cardenza CD-C18 UP column ( $150 \mathrm{~mm} \times 2.0 \mathrm{~mm}, 3.0 \mu \mathrm{m}, 120 \AA)$, and the column oven temperature was maintained at $40{ }^{\circ} \mathrm{C}$. Water with $5 \mathrm{mM}$ ammonium formate and $0.1 \%$ formic acid (A) and acetonitrile with $5 \mathrm{mM}$ ammonium formate and $0.1 \%$ formic acid (B) were used as mobile phases. The high-performance liquid chromatography (HPLC) separation used a linear gradient program of 5\% B for 0-2.0 min, 5\%-100\% B for $2.0-15.0 \mathrm{~min}, 100-5 \%$ B for 15.0-15.1 $\mathrm{min}$, and $5 \%$ B for 15.1-18.0 $\mathrm{min}$. The total run time was $18.0 \mathrm{~min}$, and the flow rate was $0.4 \mathrm{~mL} / \mathrm{min}$. In order to minimize interference between the analyte and the IS, the first feed sample was injected, and the IS mixture contained in another vial was then injected at a volume of $2 \mu \mathrm{L}$ using the autosampler pretreatment function. The analysis was performed using electrospray ionization (ESI) in positive-ion mode at $4000 \mathrm{~V}$ or in negative-ion mode at $-4000 \mathrm{~V}$. The instrument parameters were optimized as follows: interface temperature, $300{ }^{\circ} \mathrm{C}$; heat block temperature, $400{ }^{\circ} \mathrm{C}$; DL temperature, $250{ }^{\circ} \mathrm{C}$; nebulizing gas flow, $3 \mathrm{~L} / \mathrm{min}$; heating gas flow, $10 \mathrm{~L} / \mathrm{min}$; drying gas (nitrogen) flow, $10 \mathrm{~L} / \mathrm{min}$. For the quantitation and qualification of each mycotoxin, multiple-reaction monitoring (MRM) was performed. Precursor-ion- and product-ion-optimized MS/MS conditions and chromatograms for each mycotoxin are described in Table 3 and Figure 4.

Table 3. Optimized multiple-reaction monitoring (MRM) parameters for quantification and qualification of the 11 mycotoxins and internal standards (ISs).

\begin{tabular}{|c|c|c|c|c|c|c|}
\hline Compound & Ionization & $\begin{array}{c}\text { RT } \\
(\mathrm{min})\end{array}$ & $\begin{array}{c}\text { Precursor } \\
\text { Ion } \\
(m / z)\end{array}$ & $\begin{array}{c}\text { Quantitative } \\
\text { Ion } \\
(\mathrm{m} / \mathrm{z})\end{array}$ & $\begin{array}{c}\text { Qualitative } \\
\text { Ion } \\
(m / z)\end{array}$ & $\begin{array}{c}\text { Collision } \\
\text { Energy } \\
(\mathrm{eV})\end{array}$ \\
\hline Aflatoxin $\mathrm{B}_{1}$ & {$[\mathrm{M}+\mathrm{H}]^{+}$} & 10.7 & 313.0 & 285.0 & 241.0 & $-25,-40$ \\
\hline Aflatoxin $B_{2}$ & {$[\mathrm{M}+\mathrm{H}]^{+}$} & 10.4 & 315.0 & 259.1 & 287.2 & $-30,-27$ \\
\hline Aflatoxin $\mathrm{G}_{1}$ & {$[\mathrm{M}+\mathrm{H}]^{+}$} & 10.2 & 328.9 & 243.1 & 311.1 & $-27,-23$ \\
\hline Aflatoxin $\mathrm{G}_{2}$ & {$[\mathrm{M}+\mathrm{H}]^{+}$} & 9.7 & 331.0 & 313.1 & 245.2 & $-26,-31$ \\
\hline Deoxynivalenol & {$[\mathrm{M}+\mathrm{H}]^{+}$} & 6.4 & 297.0 & 249.3 & 231.1 & $-13,-14$ \\
\hline Fumonisin $B_{1}$ & {$[\mathrm{M}+\mathrm{H}]^{+}$} & 11.9 & 722.3 & 352.2 & 334.3 & $-37,-40$ \\
\hline Fumonisin $B_{2}$ & {$[\mathrm{M}+\mathrm{H}]^{+}$} & 13.1 & 706.3 & 336.4 & 354.2 & $-38,-33$ \\
\hline Ochratoxin A & {$[\mathrm{M}+\mathrm{H}]^{+}$} & 13.2 & 403.9 & 239.1 & 358.1 & $-25,-16$ \\
\hline $\mathrm{T}-2$ toxin & {$\left[\mathrm{M}+\mathrm{NH}_{4}\right]^{+}$} & 12.6 & 484.2 & 215.2 & 305.2 & $-21,-16$ \\
\hline HT-2 toxin & {$\left[\mathrm{M}+\mathrm{NH}_{4}\right]^{+}$} & 11.9 & 442.0 & 263.2 & 215.2 & $-15,-15$ \\
\hline Zearalenone & {$[\mathrm{M}-\mathrm{H}]^{-}$} & 13.3 & 317.0 & 175.3 & 131.3 & 24,29 \\
\hline${ }^{13} \mathrm{C}_{17}$ Aflatoxin $\mathrm{B}_{1}$ (IS) & {$[\mathrm{M}+\mathrm{H}]^{+}$} & 10.6 & 330.0 & 301.1 & 255.1 & $-25,-38$ \\
\hline${ }^{13} \mathrm{C}_{17}$ Aflatoxin $\mathrm{B}_{2}$ (IS) & {$[\mathrm{M}+\mathrm{H}]^{+}$} & 10.3 & 332.0 & 303.1 & 257.1 & $-28,-40$ \\
\hline${ }^{13} \mathrm{C}_{17}$ Aflatoxin $\mathrm{G}_{1}$ (IS) & {$[\mathrm{M}+\mathrm{H}]^{+}$} & 9.9 & 346.0 & 257.0 & 328.1 & $-29,-24$ \\
\hline${ }^{13} \mathrm{C}_{17}$ Aflatoxin $\mathrm{G}_{2}$ (IS) & {$[\mathrm{M}+\mathrm{H}]^{+}$} & 9.6 & 348.0 & 330.1 & 301.2 & $-25,-29$ \\
\hline${ }^{13} C_{15}$ Deoxynivalenol (IS) & {$[\mathrm{M}+\mathrm{H}]^{+}$} & 6.4 & 312.0 & 215.1 & 198.4 & $-22,-21$ \\
\hline${ }^{13} \mathrm{C}_{34}$ Fumonisin $\mathrm{B}_{1}$ (IS) & {$[\mathrm{M}+\mathrm{H}]^{+}$} & 11.8 & 756.0 & 374.4 & 356.4 & $-39,-42$ \\
\hline${ }^{13} C_{34}$ Fumonisin $B_{2}$ (IS) & {$[\mathrm{M}+\mathrm{H}]^{+}$} & 13.1 & 740.0 & 376.4 & 358.4 & $-36,-39$ \\
\hline Ochratoxin A-d5 (IS) & {$[\mathrm{M}+\mathrm{H}]^{+}$} & 13.2 & 409.2 & 363.2 & 239.1 & $-17,-25$ \\
\hline${ }^{13} \mathrm{C}_{24} \mathrm{~T}-2$ toxin (IS) & {$\left[\mathrm{M}+\mathrm{NH}_{4}\right]^{+}$} & 12.5 & 508.4 & 322.2 & 229.2 & $-16,-20$ \\
\hline${ }^{13} \mathrm{C}_{22}$ HT-2 toxin (IS) & {$\left[\mathrm{M}+\mathrm{NH}_{4}\right]^{+}$} & 11.8 & 464.0 & 278.2 & 229.2 & $-16,-16$ \\
\hline${ }^{13} \mathrm{C}_{18}$ Zearalenone (IS) & {$[\mathrm{M}-\mathrm{H}]^{-}$} & 13.2 & 335.0 & 185.2 & 140.2 & 25,31 \\
\hline
\end{tabular}



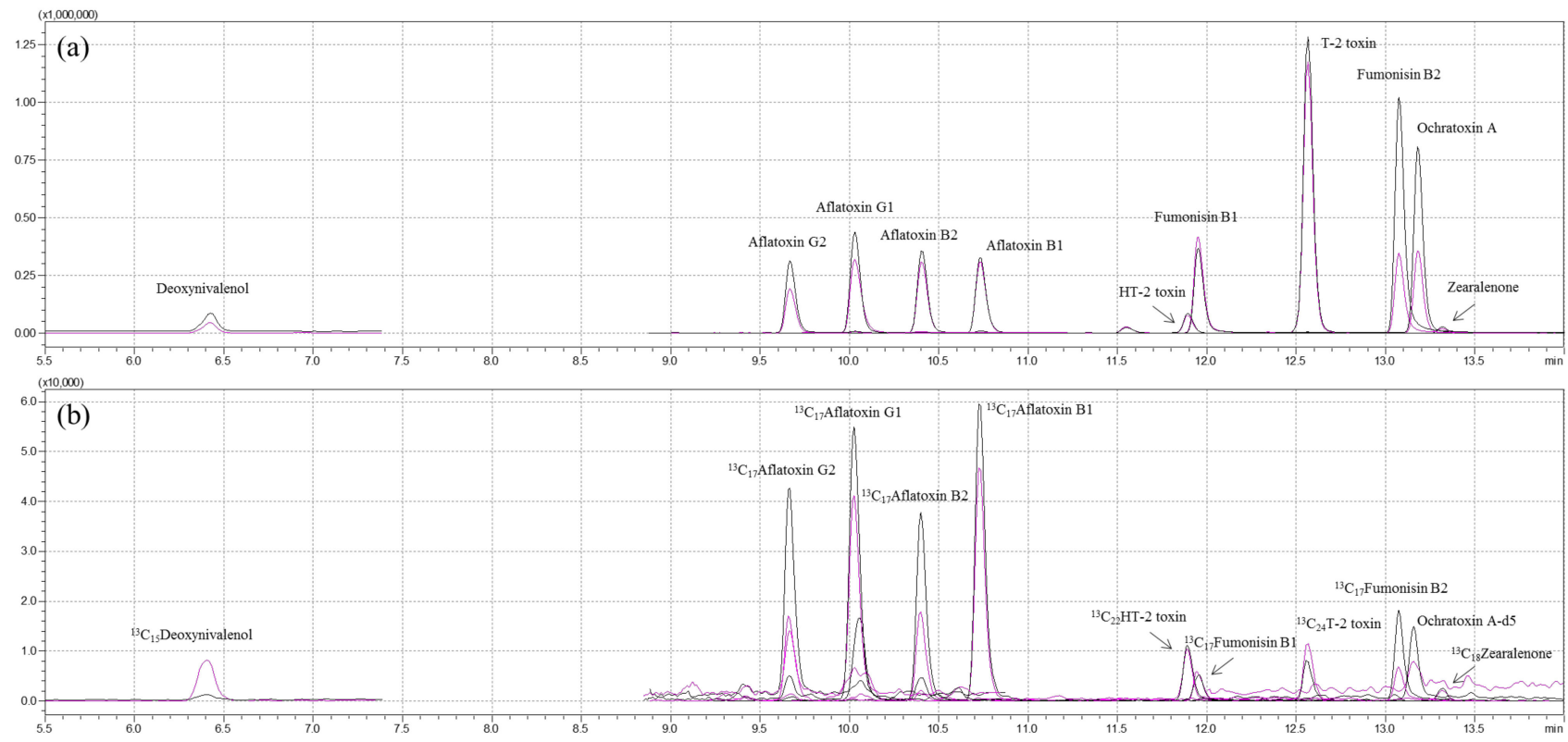

Figure 4. Representative multiple-reaction monitoring chromatograms of: (a) 11 mycotoxin standards; (b) internal standards.

\subsection{Data Analysis}

All the analytical data were processed using the Shimadzu LabSolutions LC-MS software (Shimadzu, Kyoto, Japan). The median values of experimental data were calculated using Microsoft Excel 2013 (Microsoft Co., Redmond, WA, USA). Statistical analysis of box and whisker plots was performed with SigmaPlot 12.0 (Systat Software Inc., Erkrath, Germany).

Author Contributions: Methodology, T.N. and H.J.; investigation, H.J. and H.K.; writing—original draft preparation, H.S. and S.J.; writing — review and editing, H.Y. and T.N.; software, H.S.; supervision, S.L., M.J., and H.C.; project administration, H.C. and J.M. All authors have read and agreed to the published version of the manuscript.

Funding: This research was funded by South Korea Institute of Planning and Evaluation for Technology in Food, Agriculture and Forestry (IPET) through Agro and Livestock Products Safety Flow Management Technology Development Program, funded by Ministry of Agriculture, Food and Rural Affairs (MAFRA)(318071-3).

Conflicts of Interest: The authors declare no conflict of interest.

\section{References}

1. Bennett, J.W.; Klich, M. Mycotoxins. Clin. Microbiol. Rev. 2003, 16, 497-516. [CrossRef] [PubMed]

2. Haque, M.A.; Wang, Y.; Shen, Z.; Li, X.; Saleemi, M.K.; He, C. Mycotoxin contamination and control strategy in human, domestic animal and poultry: A review. Microb. Pathog. 2020, 142, 104095-104106. [CrossRef]

3. Marin, S.; Ramos, A.J.; Cano-Sancho, G.; Sanchis, V. Mycotoxins: Occurrence, toxicology, and exposure assessment. Food Chem. Toxicol. 2013, 60, 218-237. [CrossRef]

4. Herebian, D.; Zuhlke, S.; Lamshoft, M.; Spiteller, M. Multi-mycotoxin analysis in complex biological matrices using LC-ESI/MS: Experimental study using triple stage quadrupole and LTQ-Orbitrap. J. Sep. Sci. 2009, 32, 939-948. [CrossRef]

5. Frenich, A.G.; Romero-Gonzalez, R.; Gomez-Perez, M.L.; Vidal, J.L. Multi-mycotoxin analysis in eggs using a QuEChERSbased extraction procedure and ultra-high-pressure liquid chromatography coupled to triple quadrupole mass spectrometry. J. Chromatogr. A 2011, 1218, 4349-4356. [CrossRef] [PubMed]

6. Abdallah, M.F.; Girgin, G.; Baydar, T.; Krska, R.; Sulyok, M. Occurrence of multiple mycotoxins and other fungal metabolites in animal feed and maize samples from Egypt using LC-MS/MS. J. Sci. Food Agric. 2017, 97, 4419-4428. [CrossRef] [PubMed]

7. Alonso, V.A.; Pereyra, C.M.; Keller, L.A.; Dalcero, A.M.; Rosa, C.A.; Chiacchiera, S.M.; Cavaglieri, L.R. Fungi and mycotoxins in silage: An overview. J. Appl. Microbiol. 2013, 115, 637-643. [CrossRef]

8. Binder, E.M.; Tan, L.M.; Chin, L.J.; Handl, J.; Richard, J. Worldwide occurrence of mycotoxins in commodities, feeds and feed ingredients. Anim. Feed Sci. Technol. 2007, 137, 265-282. [CrossRef] 
9. Duarte, S.C.; Lino, C.M.; Pena, A. Food safety implications of ochratoxin A in animal-derived food products. Vet. J. 2012, 192, $286-292$. [CrossRef] [PubMed]

10. Kamkar, A. A study on the occurrence of aflatoxin M1 in Iranian Feta cheese. Food Control 2006, 17, 768-775. [CrossRef]

11. Persi, N.; Pleadin, J.; Kovacevic, D.; Scortichini, G.; Milone, S. Ochratoxin A in raw materials and cooked meat products made from OTA-treated pigs. Meat Sci. 2014, 96, 203-210. [CrossRef] [PubMed]

12. Beltran, E.; Ibanez, M.; Sancho, J.V.; Hernandez, F. Determination of mycotoxins in different food commodities by ultra-high-pressure liquid chromatography coupled to triple quadrupole mass spectrometry. Rapid Commun. Mass Spectrom. 2009, 23, 1801-1809. [CrossRef]

13. Hussein, H.S.; Brasel, J.M. Toxicity, metabolism, and impact of mycotoxins on humans and animals. Toxicology 2001, 167, 101-134. [CrossRef]

14. Sobrova, P.; Adam, V.; Vasatkova, A.; Beklova, M.; Zeman, L.; Kizek, R. Deoxynivalenol and its toxicity. Interdiscip. Toxicol. 2010, 3, 94-99. [CrossRef]

15. Yu, S.; Jia, B.; Liu, N.; Yu, D.; Wu, A. Evaluation of the Individual and Combined Toxicity of Fumonisin Mycotoxins in Human Gastric Epithelial Cells. Int. J. Mol. Sci. 2020, 21, 5917. [CrossRef] [PubMed]

16. Rogowska, A.; Pomastowski, P.; Sagandykova, G.; Buszewski, B. Zearalenone and its metabolites: Effect on human health, metabolism and neutralisation methods. Toxicon 2019, 162, 46-56. [CrossRef] [PubMed]

17. International Agency for Research on Cancer. IARC Agents Classified by the IARC Monographs, Volumes 1-104; International Agency for Research on Cancer: Lyon, France, 2016; Volume 7, pp. 1-25.

18. Turner, N.W.; Subrahmanyam, S.; Piletsky, S.A. Analytical methods for determination of mycotoxins: A review. Anal. Chim. Acta 2009, 632, 168-180. [CrossRef]

19. Weaver, A.C.; Adams, N.; Yiannikouris, A. Invited Review: Use of technology to assess and monitor multimycotoxin and emerging mycotoxin challenges in feedstuffs. Appl. Anim. Sci. 2020, 36, 19-25. [CrossRef]

20. Liu, Z.; Zhao, X.; Wu, L.; Zhou, S.; Gong, Z.; Zhao, Y.; Wu, Y. Development of a Sensitive and Reliable UHPLC-MS/MS Method for the Determination of Multiple Urinary Biomarkers of Mycotoxin Exposure. Toxins 2020, 12, 193. [CrossRef] [PubMed]

21. Rausch, A.K.; Brockmeyer, R.; Schwerdtle, T. Development and Validation of a QuEChERS-Based Liquid Chromatography Tandem Mass Spectrometry Multi-Method for the Determination of 38 Native and Modified Mycotoxins in Cereals. J. Agric. Food Chem. 2020, 68, 4657-4669. [CrossRef]

22. Zhang, L.; Dou, X.W.; Zhang, C.; Logrieco, A.F.; Yang, M.H. A Review of Current Methods for Analysis of Mycotoxins in Herbal Medicines. Toxins 2018, 10, 65. [CrossRef] [PubMed]

23. Whitaker, T.B. Standardisation of mycotoxin sampling procedures: An urgent necessity. Food Control 2003, 14, 233-237. [CrossRef]

24. National Law Information Center. Available online: https://www.law.go.kr/admRulSc.do? menuId=5\&subMenuId=41 \&tabMenuId=183\&query= $\%$ EC $\% 82 \%$ AC $\%$ EB $\%$ A3 $\% 8 C \% 20 \% E B \% 93 \% B 1 \% E C \% 9 D \% 98 \% 20 \% E A \% B 8 \% B 0 \% E C \% A 4 \% 80 \% 20$ \%EB $\%$ B0\%8F\%20\%EA\%B7\%9C\%EA\%B2\%A9\#liBgcolor0 (accessed on 8 September 2021).

25. Steiner, D.; Krska, R.; Malachova, A.; Taschl, I.; Sulyok, M. Evaluation of Matrix Effects and Extraction Efficiencies of LCMS/MS Methods as the Essential Part for Proper Validation of Multiclass Contaminants in Complex Feed. J. Agric. Food Chem. 2020, 68, 3868-3880. [CrossRef] [PubMed]

26. Amirahmadi, M.; Shoeibi, S.; Rastegar, H.; Elmi, M.; Mousavi Khaneghah, A. Simultaneous analysis of mycotoxins in corn flour using LC/MS-MS combined with a modified QuEChERS procedure. Toxin Rev. 2017, 37, 187-195. [CrossRef]

27. Fabregat-Cabello, N.; Zomer, P.; Sancho, J.V.; Roig-Navarro, A.F.; Mol, H.G.J. Comparison of approaches to deal with matrix effects in LC-MS/MS based determinations of mycotoxins in food and feed. World Mycotoxin J. 2016, 9, 149-161. [CrossRef]

28. Atzrodt, J.; Derdau, V.; Kerr, W.J.; Reid, M. Deuterium- and Tritium-Labelled Compounds: Applications in the Life Sciences. Angew. Chem. Int. Ed. Engl. 2018, 57, 1758-1784. [CrossRef] [PubMed]

29. Bronsema, K.J.; Bischoff, R.; van de Merbel, N.C. Internal standards in the quantitative determination of protein biopharmaceuticals using liquid chromatography coupled to mass spectrometry. J. Chromatogr. B Analyt. Technol. Biomed. Life Sci. 2012, 893-894, 1-14. [CrossRef]

30. Trufelli, H.; Palma, P.; Famiglini, G.; Cappiello, A. An overview of matrix effects in liquid chromatography-mass spectrometry. Mass Spectrom. Rev. 2011, 30, 491-509. [CrossRef] [PubMed]

31. Azaiez, I.; Giusti, F.; Sagratini, G.; Mañes, J.; Fernández-Franzón, M. Multi-mycotoxins Analysis in Dried Fruit by LC/MS/MS and a Modified QuEChERS Procedure. Food Anal. Methods 2014, 7, 935-945. [CrossRef]

32. Jo, H.-W.; Park, M.-K.; Heo, H.-M.; Jeon, H.-J.; Choi, S.-D.; Lee, S.-E.; Moon, J.-K. Simultaneous determination of 13 mycotoxins in feedstuffs using QuEChERS extraction. Appl. Biol. Chem. 2021, 64, 34-45. [CrossRef]

33. Joo, M.; Baek, S.H.; Cheon, S.A.; Chun, H.S.; Choi, S.W.; Park, T.J. Development of aflatoxin B1 aptasensor based on wide-range fluorescence detection using graphene oxide quencher. Colloids Surf. B Biointerfaces 2017, 154, 27-32. [CrossRef]

34. Pantano, L.; La Scala, L.; Olibrio, F.; Galluzzo, F.G.; Bongiorno, C.; Buscemi, M.D.; Macaluso, A.; Vella, A. QuEChERS LC-MS/MS Screening Method for Mycotoxin Detection in Cereal Products and Spices. Int. J. Environ. Res. Public Health 2021, $18,3774$. [CrossRef]

35. Anastassiades, M.; Lehotay, S.J.; Stajnbaher, D.; Schenck, F.J. Fast and easy multiresidue method employing acetonitrile extraction/partitioning and "dispersive solid-phase extraction" for the determination of pesticide residues in produce. J. AOAC Int. 2003, 86, 412-431. [CrossRef] 
36. Alcantara-Duran, J.; Moreno-Gonzalez, D.; Garcia-Reyes, J.F.; Molina-Diaz, A. Use of a modified QuEChERS method for the determination of mycotoxin residues in edible nuts by nano flow liquid chromatography high resolution mass spectrometry. Food Chem. 2019, 279, 144-149. [CrossRef]

37. Rasmussen, R.R.; Storm, I.M.; Rasmussen, P.H.; Smedsgaard, J.; Nielsen, K.F. Multi-mycotoxin analysis of maize silage by LC-MS/MS. Anal. Bioanal. Chem. 2010, 397, 765-776. [CrossRef]

38. De Santis, B.; Debegnach, F.; Gregori, E.; Russo, S.; Marchegiani, F.; Moracci, G.; Brera, C. Development of a LC-MS/MS Method for the Multi-Mycotoxin Determination in Composite Cereal-Based Samples. Toxins 2017, 9, 169. [CrossRef]

39. Li, D.; Steimling, J.A.; Konschnik, J.D.; Grossman, S.L.; Kahler, T.W. Quantitation of Mycotoxins in Four Food Matrices Comparing Stable Isotope Dilution Assay (SIDA) with Matrix-Matched Calibration Methods by LC-MS/MS. J. AOAC Int. 2019, 102, 1673-1680. [CrossRef] [PubMed]

40. Facorro, R.; Llompart, M.; Dagnac, T. Combined (d)SPE-QuEChERS Extraction of Mycotoxins in Mixed Feed Rations and Analysis by High Performance Liquid Chromatography-High-Resolution Mass Spectrometry. Toxins 2020, 12, 206. [CrossRef] [PubMed]

41. González-Jartín, J.M.; Alfonso, A.; Sainz, M.J.; Vieytes, M.R.; Botana, L.M. Multi-detection method for mycotoxins with a modified QuEChERS extraction in feed and development of a simple detoxification procedure. Anim. Feed Sci. Technol. 2021, $272,114745$. [CrossRef]

42. Warth, B.; Parich, A.; Atehnkeng, J.; Bandyopadhyay, R.; Schuhmacher, R.; Sulyok, M.; Krska, R. Quantitation of mycotoxins in food and feed from Burkina Faso and Mozambique using a modern LC-MS/MS multitoxin method. J. Agric. Food Chem. 2012, 60, 9352-9363. [CrossRef]

43. AOAC. Sub-Committee on Feed Additives and Contaminants; AOAC: Rockville, MD, USA, 2008; pp. $2041-2042$.

44. Food and Agriculture Organization. Codex General Standard for Contaminants and Toxins in Food and Feed (Codex Stan 193-1995); Food and Agriculture Organization: Geneva, Switzerland, 1995.

45. Hygienical Standard for Feeds; GB/T 13078-2017; National Criterion of China: Beijing, China, 2017.

46. Food and Agricultural Materials Inspection Center Reference Value of Harmful Substances in Feed. Available online: http: //www.famic.go.jp/ffis/feed/r_safety/r_feeds_safetyj22.html (accessed on 8 September 2021).

47. European Commission (EC). COMMISSION REGULATION (EC) No 401/2006 of 23 February 2006 laying down the methods of sampling and analysis for the official control of the levels of mycotoxins in foodstuffs. Off. J. Eur. Union 2006, L70, 12-34.

48. Kim, D.H.; Hong, S.Y.; Kang, J.W.; Cho, S.M.; Lee, K.R.; An, T.K.; Lee, C.; Chung, S.H. Simultaneous Determination of MultiMycotoxins in Cereal Grains Collected from South Korea by LC/MS/MS. Toxins 2017, 9, 106. [CrossRef]

49. Kim, H.J.; Lee, M.J.; Kim, H.J.; Cho, S.K.; Park, H.J.; Jeong, M.H.; Yildiz, F. Analytical method development and monitoring of Aflatoxin B1, B2, G1, G2 and Ochratoxin A in animal feed using HPLC with Fluorescence detector and photochemical reaction device. Cogent Food Agric. 2017, 3, 1419788-1419795. [CrossRef]

50. Ma, R.; Zhang, L.; Liu, M.; Su, Y.T.; Xie, W.M.; Zhang, N.Y.; Dai, J.F.; Wang, Y.; Rajput, S.A.; Qi, D.S.; et al. Individual and Combined Occurrence of Mycotoxins in Feed Ingredients and Complete Feeds in China. Toxins 2018, 10, 113. [CrossRef] [PubMed]

51. Zhao, L.; Zhang, L.; Xu, Z.; Liu, X.; Chen, L.; Dai, J.; Karrow, N.A.; Sun, L. Occurrence of Aflatoxin B1, deoxynivalenol and zearalenone in feeds in China during 2018-2020. J. Anim. Sci. Biotechnol. 2021, 12, 74. [CrossRef] [PubMed]

52. Nomura, M.; Aoyama, K.; Ishibashi, T. Sterigmatocystin and aflatoxin B1 contamination of corn, soybean meal, and formula feed in Japan. Mycotoxin Res. 2018, 34, 21-27. [CrossRef]

53. Uegaki, R.; Tsunoda, A. Mycotoxin Contamination in Japanese Domestic Feed. Food Saf. 2018, 6, 96-100. [CrossRef]

54. Grajewski, J.; Blajet-Kosicka, A.; Twaruzek, M.; Kosicki, R. Occurrence of mycotoxins in Polish animal feed in years 2006-2009. J. Anim. Physiol. Anim. Nutr. 2012, 96, 870-877. [CrossRef] [PubMed]

55. Bilal, T.; Aksakal, D.H.; Sünnetci, S.; Keser, O.; Eseceli, H. Detection of Aflatoxin, Zearalenone and Deoxynivalenol in Some Feed and Feedstuffs in Turkey. Pak. Vet. J. 2014, 34, 459-463.

56. Arroyo-Manzanares, N.; Rodriguez-Estevez, V.; Arenas-Fernandez, P.; Garcia-Campana, A.M.; Gamiz-Gracia, L. Occurrence of Mycotoxins in Swine Feeding from Spain. Toxins 2019, 11, 342. [CrossRef]

57. Gruber-Dorninger, C.; Jenkins, T.; Schatzmayr, G. Global Mycotoxin Occurrence in Feed: A Ten-Year Survey. Toxins 2019, 11, 375. [CrossRef] [PubMed]

58. European Commission (EC). COMMISSION RECOMMENDATION of 17 August 2006 on the presence of deoxynivalenol, zearalenone, ochratoxin A, T-2 and HT-2 and fumonisins in products intended for animal feeding. Off. J. Eur. Union 2006, L229, 7-9.

59. Park, J.; Chang, H.; Kim, D.; Chung, S.; Lee, C. Long-Term Occurrence of Deoxynivalenol in Feed and Feed Raw Materials with a Special Focus on South Korea. Toxins 2018, 10, 127. [CrossRef]

60. Wu, L.; Li, J.; Li, Y.; Li, T.; He, Q.; Tang, Y.; Liu, H.; Su, Y.; Yin, Y.; Liao, P. Aflatoxin B1, zearalenone and deoxynivalenol in feed ingredients and complete feed from different Province in China. J. Anim. Sci. Biotechnol. 2016, 7, 63. [CrossRef]

61. Almeida, I.; Martins, H.M.; Santos, S.; Costa, J.M.; Bernardo, F. Co-occurrence of mycotoxins in swine feed produced in Portugal. Mycotoxin Res. 2011, 27, 177-181. [CrossRef] [PubMed]

62. Kim, D.H.; Lee, I.H.; Do, W.H.; Nam, W.S.; Li, H.; Jang, H.S.; Lee, C. Incidence and levels of deoxynivalenol, fumonisins and zearalenone contaminants in animal feeds used in Korea in 2012. Toxins 2013, 6, 20-32. [CrossRef] [PubMed]

63. Park, J.; Chang, H.; Hong, S.; Kim, D.; Chung, S.; Lee, C. A Decrease of Incidence Cases of Fumonisins in South Korean Feedstuff between 2011 and 2016. Toxins 2017, 9, 286. [CrossRef] 
64. Ok, H.E.; Kang, Y.W.; Kim, M.; Chun, H.S. T-2 and HT-2 toxins in cereals and cereal-based products in South Korea. Food Addit. Contam. Part B Surveill. 2013, 6, 103-109. [CrossRef] [PubMed]

65. Chang, H.; Kim, W.; Park, J.H.; Kim, D.; Kim, C.R.; Chung, S.; Lee, C. The Occurrence of Zearalenone in South Korean Feedstuffs between 2009 and 2016. Toxins 2017, 9, 223. [CrossRef]

66. Bensassi, F.; Gallerne, C.; Sharaf el Dein, O.; Hajlaoui, M.R.; Lemaire, C.; Bacha, H. In vitro investigation of toxicological interactions between the fusariotoxins deoxynivalenol and zearalenone. Toxicon 2014, 84, 1-6. [CrossRef] [PubMed]

67. Le Drean, G.; Auffret, M.; Batina, P.; Arnold, F.; Sibiril, Y.; Arzur, D.; Parent-Massin, D. Myelotoxicity of trichothecenes and apoptosis: An in vitro study on human cord blood CD34+ hematopoietic progenitor. Toxicol. In Vitro 2005, 19, 1015-1024. [CrossRef] [PubMed]

68. Sun, L.H.; Lei, M.Y.; Zhang, N.Y.; Zhao, L.; Krumm, C.S.; Qi, D.S. Hepatotoxic effects of mycotoxin combinations in mice. Food Chem. Toxicol. 2014, 74, 289-293. [CrossRef] [PubMed]

69. Sun, L.H.; Lei, M.Y.; Zhang, N.Y.; Gao, X.; Li, C.; Krumm, C.S.; Qi, D.S. Individual and combined cytotoxic effects of aflatoxin B1, zearalenone, deoxynivalenol and fumonisin B1 on BRL 3A rat liver cells. Toxicon 2015, 95, 6-12. [CrossRef] [PubMed]

70. Lee, H.J.; Ryu, D. Worldwide Occurrence of Mycotoxins in Cereals and Cereal-Derived Food Products: Public Health Perspectives of Their Co-occurrence. J. Agric. Food Chem. 2017, 65, 7034-7051. [CrossRef] [PubMed]

71. Sweeney, M.J.; Dobson, A.D. Mycotoxin production by Aspergillus, Fusarium and Penicillium species. Int. J. Food Microbiol. 1998, 43, 141-158. [CrossRef]

72. Atalla, M.M.; Hassanein, N.M.; El-Beih, A.A.; Youssef, Y.A. Mycotoxin production in wheat grains by different Aspergilli in relation to different relative humidities and storage periods. Nahrung 2003, 47, 6-10. [CrossRef]

73. Streit, E.; Schatzmayr, G.; Tassis, P.; Tzika, E.; Marin, D.; Taranu, I.; Tabuc, C.; Nicolau, A.; Aprodu, I.; Puel, O.; et al. Current situation of mycotoxin contamination and co-occurrence in animal feed-Focus on Europe. Toxins 2012, 4, 788-809. [CrossRef] [PubMed]

74. Mankevičienè, A.; Butkutè, B.; Dabkevičius, Z. Peculiarities of cereal grain co-contamination with Fusarium mycotoxins. Zemdirb. Agric. 2011, 98, 415-420.

75. Streit, E.; Naehrer, K.; Rodrigues, I.; Schatzmayr, G. Mycotoxin occurrence in feed and feed raw materials worldwide: Long-term analysis with special focus on Europe and Asia. J. Sci. Food Agric. 2013, 93, 2892-2899. [CrossRef] [PubMed]

76. Bryla, M.; Waskiewicz, A.; Podolska, G.; Szymczyk, K.; Jedrzejczak, R.; Damaziak, K.; Sulek, A. Occurrence of 26 Mycotoxins in the Grain of Cereals Cultivated in Poland. Toxins 2016, 8, 160. [CrossRef] 